\title{
Variation in Vegetation and Ecosystem Carbon Stock Due to the Conversion of Disturbed Forest to Oil Palm Plantation in Peruvian Amazonia
}

\author{
Natalia Málaga, ${ }^{1 *}$ Kristell Hergoualc'h,${ }^{1}$ Gerald Kapp, ${ }^{2}$ and \\ Christopher Martius ${ }^{1,3}$
}

\begin{abstract}
${ }^{1}$ Center for International Forestry Research (CIFOR), Jl. CIFOR, Situ Gede, Bogor 16115, Indonesia; ${ }^{2}$ Institute of International Forestry and Forest Products, Technische Universität Dresden, Pienner Straße 7, 01737 Tharandt, Germany; ${ }^{3}$ Center for International Forestry Research (CIFOR) Germany gGmbH, Charles-de-Gaulle-Strasse 5, 53113 Bonn, Germany
\end{abstract}

\begin{abstract}
Peruvian national and regional plans promoting oil palm have prompted a rapid expansion of the crop in the Amazonian region. This expansion has taken place primarily at the expense of forest, both undisturbed and disturbed. Assessments of carbon emissions from forest-to-oil palm conversion have essentially been confined to Southeast Asia, and research on Peruvian Amazonian forests has mainly targeted undisturbed sites. This study characterizes the vegetation structure and composition of disturbed forests and smallholder oil palm plantations and evaluates the change in ecosystem (that is, phytomass and soil) carbon stocks associated with forest-to-oil palm conversion. Inventories were conducted in four degraded forest sites
\end{abstract}

Received 8 December 2019; accepted 31 May 2020; published online 17 June 2020

Electronic supplementary material: The online version of this article (https://doi.org/10.1007/s10021-020-00521-8) contains supplementary material, which is available to authorized users.

Authors' Contributions KH conceived the study and NM contributed with new methods and models; NM and KH performed the research, analyzed the data and wrote the paper; GK and CM contributed with new methods. All authors contributed critically to the research and writing of the manuscript.

*Corresponding author; e-mail: natalia.malaga.duran@gmail.com neighboring six oil palm plantation sites in Ucayali. Time-averaged carbon stocks over the 30-year oil palm rotation were computed from models developed upon the sampled chronosequence ( 1 to 28 years old). Disturbed forests harbored species typical of primary forests, pioneer species and gaps opportunistic species. Their tree basal area $\left(18.7 \pm 1.4 \mathrm{~m}^{2} \mathrm{ha}^{-1}\right)$ and above-ground $\mathrm{C}$ stock $\left(71.3 \pm 4.2 \mathrm{Mg} \mathrm{C}^{-1}\right)$ were, respectively, 50 and $60 \%$ of the values of undisturbed forests from the literature. The growth curve for oil palm aboveground biomass was consistently below models developed for plantations in Indonesia. Thirty-year time-averaged ecosystem $\mathrm{C}$ stock $\left(\mathrm{Mg} \mathrm{C} \mathrm{ha}^{-1}\right)$ in oil palm plantations $(78.2 \pm 2.0)$ represented $55 \%$ of the stock in disturbed forest (140.9 \pm 5.8$)$, resulting in a $62.7 \pm 6.1$ loss from such conversion. These results reinforce recommendations to redirect oil palm expansion toward low-carbon degraded lands, sparing disturbed and undisturbed forests.

Key words: Floristic composition; Forest structure; Degraded forest; Inventory; Phytomass; Secondary forest; Soil carbon stock; Time-average. 


\section{HighLIGHTS}

- Disturbed forests sustain vital ecosystem services including biodiversity and $\mathrm{C}$ storage

- The growth curve of oil palm above-ground biomass is lower in Peru than in Indonesia

- Disturbed forest conversion to oil palm decreases ecosystem C stock by $45 \%$

\section{INTRODUCTION}

Amazonian tropical forests provide essential ecosystem services at local and global scales. Peru is the second largest Amazonian forest country, with as much as $53 \%$ of the territory covered by this species-rich biome (Potapov and others 2014; Ministerio del Ambiente 2015). During 2001-2014, Peru lost 1.7 M ha or $2 \%$ of its Amazonian forest, following an increasing deforestation trend over time (Ministerio del Ambiente 2016; Vargas Gonzáles and others 2014). The main regions affected by deforestation include San Martin, Loreto and Ucayali. In its 2015 Nationally Determined Contribution (NDC), the country pledged to reduce its greenhouse emissions by $30 \%$ with respect to the projected business-as-usual emissions in 2030 (Peru 2015). Half of these emissions reductions are expected in the land use, land-use change and forestry sector. Historical deforestation has been associated with small-scale migratory agriculture, though from 2007 onward industrial farming in the Amazonian regions of Loreto and Ucayali and escalating mining in Madre de Dios have been identified as additional drivers of deforestation (Ministerio del Ambiente 2015, 2016; Potapov and others 2014; Sy and others 2015).

In Ucayali, anthropogenic disturbance began around 1943, when the Lima-Pucallpa highway was built, triggering the development of secondary roads and the establishment of new settlements (Galván and others 2000). Around 1980, agricultural and cattle raising activities expanded; first as subsistence farming and later with plantation of perennial crops including cacao, oil palm and coca (Galván and others 2000; Fujisaka and White 1998). By 1996, Pucallpa settlers had already cleared more than half of their lands leaving a heterogeneous landscape mainly composed of forest patches, fallows and pastures; with permanent and annual crops in lower proportion (Fujisaka and White 1998). At the same time, forest logging turned into an intense activity in the area. Of the Peruvian Amazonian regions, Ucayali had the highest round wood and sawn timber production in the country (Ministerio de Agricultura 1999).

Despite continued anthropogenic pressures on Peruvian forests, limited research has been conducted to evaluate the characteristics of disturbed forests including their structure, composition and carbon (C) stocks. Moreover, studies performed across the tropics share limited agreement on how, for instance, logging activities may affect tropical forests. A study in African semi-deciduous forests found no difference in tree species composition between 18-year-old post-harvest stands that had been selectively logged and analogous unlogged stands. Notwithstanding, these stands did differ in structure and recruitment with reduced sapling and tree density in harvested stands (Hall and others 2003). Lowland forests in Ucayali regenerate rapidly after slashing and burning in comparison with poorer soil sites in Amazonia, but their floristic composition could take centuries to resemble that of an old-growth forest (Tournon and Riva 2001; Rozendaal and others 2019). According to Jakovac and others (2016) and Alva Vásquez and Lombardi (2000), factors that influence the most forest succession in Ucayali in terms of composition and productivity are soil fertility, intensity of the previous land use, economic activities in the surroundings and distance to primary forest patches. For instance, secondary forests along the Federico Basadre highway near Pucallpa city have a lower density of small-diameter trees in comparison with areas located further from the highway due to longer and more intense disturbance, poorer soils and less seed bank primary forests across the landscape (Kommeter 1987). There is also limited research on how forest disturbance affects $\mathrm{C}$ stocks in the Peruvian Amazonia; the few results available draw upon scattered studies using heterogenous methods, having different site history and suffering from statistical weaknesses (for example, lack of replicates and no statistical assessment) (Alegre and others 2003; Lapeyre and others 2004; Meza Doza 2016). A synthesis from chronosequence studies in Neotropical lowland secondary forests found an average recovery of about $60 \mathrm{Mg} \mathrm{C} \mathrm{ha}{ }^{-1}$ in aboveground biomass in 20 years (Poorter and others 2016).

Peru has less land area allocated to oil palm than other Latin American countries (for example, Colombia, Ecuador and Brazil) and considers the crop of being of national interest (Ministerio de Agricultura 2016). Taxation incentives were introduced to oil palm farmers around the year 2000 with the purpose of tackling the economic and ecological effects of shifting cultivation and eradi- 

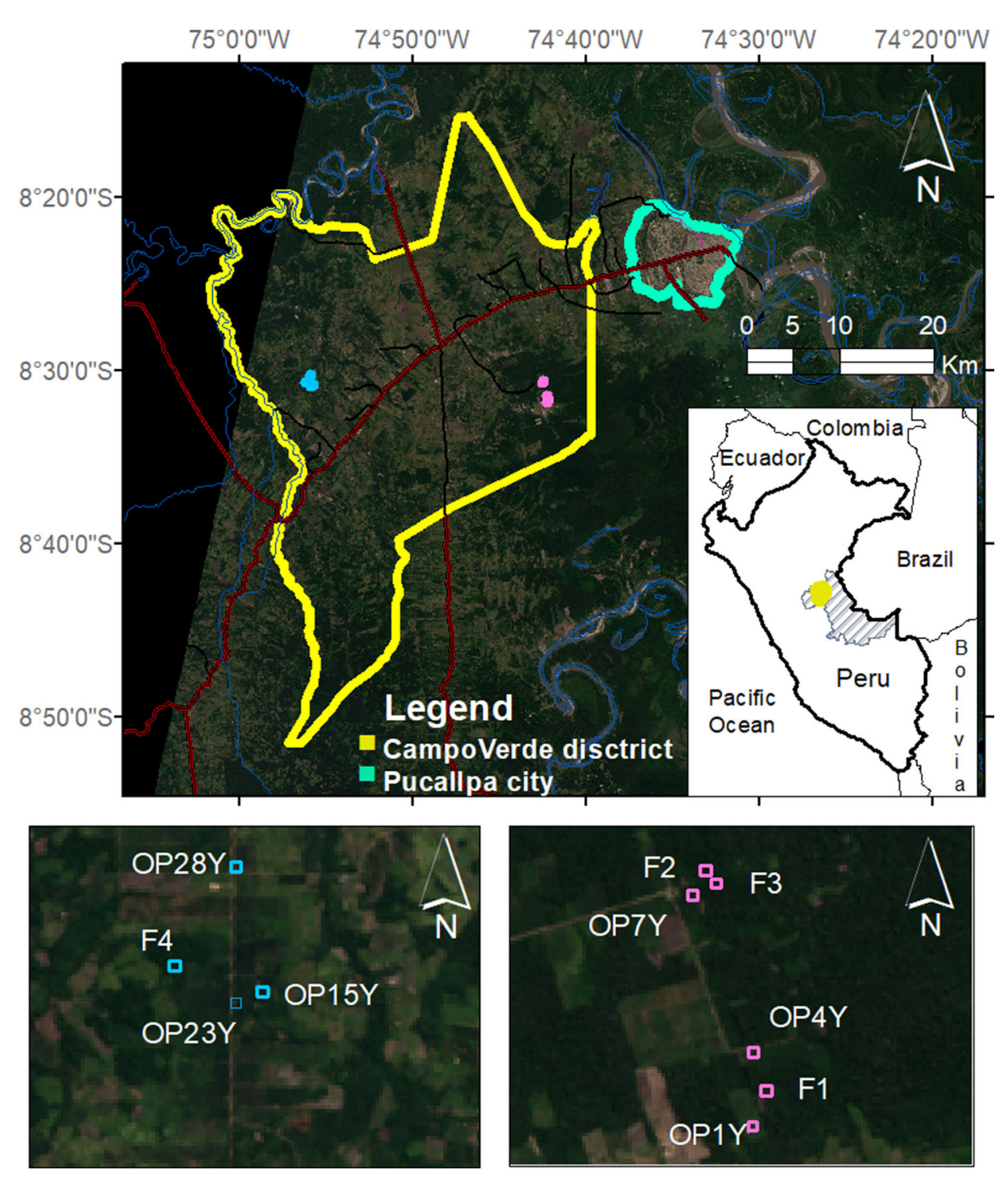

Figure 1. Location of the study area in the Campo Verde district, region of Ucayali. Disturbed forests (F) and oil palm plantation (OP) sites located in the Nuevo San Pedro village are displayed in blue (left sub-panel), sites in the Tupac Amaru Limon village in pink (right sub-panel). Landsat 8 OLI 2015 satellite image in RGB (432).

cating illicit crops. At the same time, a national plan on oil palm for the period 2000-2010 identified a 1.4 Mha area suitable for the crop and promoted the development of 50,000 ha (Ministerio de Agricultura 2001). A biofuel law enforced in 2009 also triggered the expansion of the crop by setting a $5 \%$ share of biofuel in diesel as an effort to reduce greenhouse emissions from the car fleet (Dammert 2016). As a result, by 2015 , oil palm plantations covered 77,537 ha of the territory; they were mainly concentrated in the regions of San Martin and Ucayali (Gobierno Regional de Ucayali 2016a). Their extent in Ucayali grew sevenfold in eight years (from 5000 ha in 2008 to 35,000 ha in 2016;
Gobierno Regional de Ucayali 2016a). The region has established a plan targeting 60,000 ha by 2026 (Gobierno Regional de Ucayali 2016a). While the 2000-2010 national plan for oil palm encouraged its expansion in deforested or degraded lands, no legal framework confining plantations to such areas was defined, and the crop developed mostly at the expense of both disturbed and undisturbed forests (Barrantes and others 2016; Gutiérrez-Vélez and others 2011). Vijay and others (2018) estimated that oil palm contributed $20 \%$ to overall agricultural deforestation in Peru in 2013 while representing less than $4 \%$ of the cropland area in Amazonia. In Ucayali, almost three quarters of the 
Table 1. Location, Characteristics and Land-Use (LU) History of Study Sites

\begin{tabular}{|c|c|c|c|c|c|c|c|c|}
\hline \multirow[t]{2}{*}{ Site $^{a}$} & \multirow[t]{2}{*}{ Village $^{\mathrm{b}}$} & \multicolumn{2}{|l|}{ Coordinates } & \multirow{2}{*}{$\begin{array}{l}\text { Size of } \\
\text { the LU } \\
\text { (ha) }\end{array}$} & \multirow{2}{*}{$\begin{array}{l}\text { Distance of OP } \\
\text { to F edge }(\mathrm{m})\end{array}$} & \multirow{2}{*}{$\begin{array}{l}\text { Interim LU } \\
\text { before OP }\end{array}$} & \multirow{2}{*}{$\begin{array}{l}\text { Duration } \\
\text { interim LU } \\
\text { (years) }\end{array}$} & \multirow{2}{*}{$\begin{array}{l}\text { Land- } \\
\text { clearing } \\
\text { fires }(n)\end{array}$} \\
\hline & & $S^{\circ}$ & $\mathbf{W}^{\circ}$ & & & & & \\
\hline Fl & TAL & $08^{\circ} 31^{\prime} 39.6^{\prime \prime}$ & $74^{\circ} 42^{\prime} 14.4^{\prime \prime}$ & 4 & - & - & - & - \\
\hline $\mathrm{F} 2$ & TAL & $08^{\circ} 30^{\prime} 40.0^{\prime \prime}$ & $74^{\circ} 42^{\prime} 30.3^{\prime \prime}$ & 17 & - & - & - & - \\
\hline F3 & TAL & $08^{\circ} 30^{\prime} 35.6^{\prime \prime}$ & $74^{\circ} 42^{\prime} 32.0^{\prime \prime}$ & 12 & - & - & - & - \\
\hline F4 & NSP & $08^{\circ} 30^{\prime} 42.0^{\prime \prime}$ & $74^{\circ} 56^{\prime} 14.0^{\prime \prime}$ & 2 & - & - & - & - \\
\hline OPlY & TAL & $08^{\circ} 31^{\prime} 51.2^{\prime \prime}$ & $74^{\circ} 42^{\prime} 18.6^{\prime \prime}$ & 2 & 50 & Fallow & 3 & 1 \\
\hline OP4Y & TAL & $08^{\circ} 31^{\prime} 30.6^{\prime \prime}$ & $74^{\circ} 42^{\prime} 19.3^{\prime \prime}$ & 2 & 20 & n.a. & n.a. & 1 \\
\hline OP7Y & TAL & $08^{\circ} 30^{\prime} 42.9^{\prime \prime}$ & $74^{\circ} 42^{\prime} 37.1^{\prime \prime}$ & 6 & 200 & $\mathrm{Kudzu}^{\mathrm{b}}$ & 1 & 1 \\
\hline OP15Y & NSP & $08^{\circ} 30^{\prime} 51.4^{\prime \prime}$ & $74^{\circ} 55^{\prime} 47.5^{\prime \prime}$ & 2.5 & 250 & $\mathrm{Kudzu}^{\mathrm{b}}$ & n.a. & 1 \\
\hline OP23Y & NSP & $08^{\circ} 30^{\prime} 55.2^{\prime \prime}$ & $74^{\circ} 55^{\prime} 54.0^{\prime \prime}$ & 4 & 400 & Coca & n.a. & n.a. \\
\hline OP28Y & NSP & $08^{\circ} 30^{\prime} 13.5^{\prime \prime}$ & $74^{\circ} 55^{\prime} 55.0^{\prime \prime}$ & 25 & 400 & n.a. & n.a. & 1 \\
\hline
\end{tabular}

land converted to oil palm plantations during 2000-2010 took place in forested areas (GutiérrezVélez and others 2011 ) decreasing to 57\% between 2010 and 2016 (Glinskis and Gutiérrez-Vélez 2019). Medium and smallholders accounted for larger areas of expansion than large-scale producers (2.5 times more) and developed their plantations mainly in disturbed forests, as opposed to largescale producers who used mainly undisturbed forests (Gutiérrez-Vélez and others 2011; Glinskis and Gutiérrez-Vélez 2019).

Loss of $\mathrm{C}$ from forest conversion to oil palm plantation has essentially been studied in Southeast Asia where the crop has predominantly expanded, while research in South America remains almost inexistent. The growth and productivity of the crop varies over time during the rotation cycle and depends on management practices such as planting material, fertilization, harvesting and maintenance regimes as well as on environmental factors (Potter 2015). Suitable climatic conditions combined with breeding techniques and optimized fertilization have favored yields up to $20-30 \mathrm{Mg}$ of fresh fruit bunches (FFB) ha $\mathrm{ha}^{-1} \mathrm{y}^{-1}$ in Indonesia and Malaysia (Potter 2015; Corley and Tinker 2003). In contrast, Peruvian smallholders produce on average only 13.7 $\mathrm{Mg}$ FFB ha ${ }^{-1} \mathrm{y}^{-1}$ likely due to deficient techniques and management practices such as inadequate planting density, insufficient fertilization due to limited incomes and supplies, absence of irrigation, among others (Potter 2015; Ministerio de Agricultura 2016; Corley and Tinker 2003). Differences in management affect not only the crop yield but also its growth and ultimately $\mathrm{C}$ stocks in the plantation. Several studies conducted in Southeast Asia found lower C stocks in oil palm stands managed by medium- and smallholders than in stands of large-scale producers (Chase and Henson 2010; Khasanah and others 2015a; Henson 2017). As the plantation C stocks change over time, assessing $\mathrm{C}$ loss from forest to oil palm conversion requires knowledge on the averaged stock over the oil palm rotation cycle which lasts from 25 to 30 years (Ministerio de Agricultura 2016). A common approach for doing so consists in modeling the change of $\mathrm{C}$ stocks using data collected along a chronosequence.

This research aims to characterize the floristic composition and structure of disturbed forest and the change in ecosystem $\mathrm{C}$ stock due to the conversion of disturbed forests to smallholder oil palm plantations in the Peruvian Amazonia. The ecosystem $\mathrm{C}$ stock hereafter refers to the stock contained in all studied pools including above- and below-ground biomass, understory, dead wood, palm fronds, litter and soil. Disturbed forest here refers to the mosaic of anthropogenic intervened forests as found in the region of Ucayali, which includes residual forests resulting from past logging activities and secondary forests re-growing after long fallows (Smith 1999). Oil palm plantations were all in their first rotation cycle, consistent with the recent expansion of the crop in the country. We address three research questions: (1) What are the floristic and structural features of disturbed forests and how much $\mathrm{C}$ do disturbed forests store? (2) How does the structure and $\mathrm{C}$ stock of oil palm plantations change over time and how much $\mathrm{C}$ do they store over their first rotation? and (3) How much $\mathrm{C}$ is lost from the conversion of disturbed forest to oil palm plantation? 


\section{Materials ANd Methods}

\section{Study Area and Experimental Design}

The study was located nearby the villages of Nuevo San Pedro (NSP) and Tupac Amaru Limon (TAL) about 20 and $40 \mathrm{~km}$ from Pucallpa city, in the district of Campo Verde, region of Ucayali (Figure 1). Annual temperatures in the area are relatively constant between 24 and $26^{\circ} \mathrm{C}$, with an annual mean of $25^{\circ} \mathrm{C}$, and average annual precipitation fluctuates between 1600 and $2300 \mathrm{~mm}$ with two to four dry months (precipitation $<100 \mathrm{~mm}$ month $^{-1}$ ) per year between May and August (Campo Verde meteorological stations, Gobierno Regional de Ucayali 2016b). The TAL and NSP villages are on a terrace elevated 160-192 m a.s.l., and present similar well-drained clay-loam soils, classified as Luvisols and Cambisols (Gobierno Regional de Ucayali 2016c).

We employed a space-for-time substitution approach for assessing the changes in C stocks. This extensively used method infers past trajectories from contemporary patterns and assumes that the observed differences can be attributed to land use or land-use change and are not inherent to site differences (Blois and others 2013). We selected carefully a total of four forest and six oil palm plantation (Elaeis guineensis) sites. Three of the forest sites were adjacent to young oil palm plantations aged 1, 4 and 7 years, nearby TAL village (Figure 1). The fourth forest site was near the oldest plantations aged 15, 23 and 28 years, close to NSP village. The lack of remaining forest around NSP hampered the inclusion of additional forest sites to reach an equal number of forest and plantation replicates in the experimental design.

All forest sites were disturbed and assumed to be representative of the heterogonous remnant forest landscape found next to oil palm plantations boundaries in the area, and to share a similar landuse history (according to interviews with local actors). The oil palm sites were all situated in former disturbed forests according to historical observations from satellite imagery (S1 and S2 in Supplemental Material 1). They had been either converted directly to plantation or left as fallow, used as coca field or cultivated with a ground cover for some years before being planted (Table 1), as typically practiced in the region. All of them were in their first rotation, and most of them had been subject to at least one land-clearing fire prior to planting. Planting material was either ASD (Costa Rica) or CIRAD $^{\circledR}$ seeds. Fertilizer was applied irregularly depending on each individual small- holder. Older stands received in two applications around $1.5-3.5 \mathrm{~kg} \mathrm{palm}^{-1} \mathrm{y}^{-1}$ of rock phosphate $\left(24 \% \mathrm{P}_{2} \mathrm{O}_{5}+33 \% \mathrm{CaO}\right)$, urea (46\% Nitrogen), potassium chloride $\left(60 \% \mathrm{~K}_{2} \mathrm{O}\right)$ and compounds of $\mathrm{MgO}+\mathrm{B}+\mathrm{S}$ in different concentrations. Younger stands ( $<5$ years) received less than $2 \mathrm{~kg}$ of these fertilizers per palm and year.

The level of disturbance in forests was evaluated through inspection of their composition, structure and $\mathrm{C}$ stocks as compared to a referential undisturbed baseline drawn upon an exhaustive literature review. It was beyond the scope of this study to measure $\mathrm{C}$ accumulation in disturbed forests according to disturbance age. The change in $\mathrm{C}$ stocks over time in plantations was modeled over a typical 30-year life cycle, and their time-average stocks were evaluated against stocks in disturbed forests for assessing $\mathrm{C}$ losses from the conversion.

\section{Phytomass and Soil Inventories}

The inventories were carried out between June and August 2015. Additional data on oil palm trunks were collected in March 2018. We used a nested plot design for sampling various pools. The approach was specifically designed to capture the spatial variability of disturbed forests and accommodate the regular planting scheme of oil palms while maintaining harmonized sampling methods across land uses. Pools inventoried included aboveground biomass (AGB), below-ground biomass (BGB), understory, standing and fallen dead wood (DW), oil palm fronds, litter and soil.

\section{Disturbed Forests}

The AGB of trees and standing DW with a stem diameter at breast height (DBH) greater than $30 \mathrm{~cm}$ was measured in 1 ha plots. One plot per site was positioned at a minimum distance of $20 \mathrm{~m}$ from the edge of the forest. Individuals with a DBH between 5 and $30 \mathrm{~cm}$ were measured in three $16 \mathrm{~m} \times 36 \mathrm{~m}$ subplots positioned randomly within the 1 ha plot (see nested plot design S3 in Supplemental Material 1). The DBH of trees was measured using a metric tape. The height for measuring diameter of atypical trees was located using standard methods (Phillips and others 2016). Standing dead trees were classified into three decay statues (D): individuals without leaves retaining most branches (Dl), individuals without leaves and small branches retaining large branches (D2) and individuals without leaves and branches retaining mainly the stem (D3) (Kauffman and Donato 2012). The height of D3 individuals was measured from the soil surface until the highest point using a cli- 
nometer. Tree species were identified at species, genus and family level by a botanist. Whenever identification could not be performed in situ, leaf samples were collected in the field, air-dried and identified at the herbarium of the Instituto de Investigación de la Amazonía Peruana (IIAP).

Fallen DW was measured using the linear intersect technique, that is, by counting the woody pieces intersecting a vertical sampling plane (Kauffman and Donato 2012). In each of the $16 \mathrm{~m} \times 36 \mathrm{~m}$ subplots, three 4.5 -m-radius circular plots were established where four $4.5-\mathrm{m}$ woody debris line transects were laid out perpendicular to each other. Diameter and decay status (sound or rotten) of all large woody debris (diameter $\geq 8 \mathrm{~cm}$ ) were recorded along each transect. All medium woody debris (diameter $2-8 \mathrm{~cm}$ ) was counted, and the diameter of ten randomly chosen medium pieces was measured, less than ten in cases of scarcity. For specific gravity and carbon content determination, around ten pieces were randomly collected (inside the plot but outside the subplot) for each wood decay category (medium, large sound, large rotten). Their volume was estimated by measuring their size (length, diameter) and their dry mass by weighing them after oven-drying at $65^{\circ} \mathrm{C}$ until constant weight. Three replicates for each category (medium, large sound and large rotten), each made up of three mixed sub-subsamples randomly chosen, were analyzed for C content.

Understory vegetation and litter were sampled in a $0.5 \mathrm{~m} \times 0.5 \mathrm{~m}$ quadrat established in each circular plot. All the vegetation growing on the surface (for example, ferns) was destructively sampled and all the litter collected. The wet mass of understory and litter was weighed in the field, and one sub-sample per subplot was oven-dried at $65^{\circ} \mathrm{C}$ until constant mass. Three replicates of understorey and litter, each made up of three mixed sub-subsamples from the three transects, were analyzed for carbon content.

Soil sampling was performed in each subplot at two positions chosen at random where a $30-\mathrm{cm}$ deep pit was excavated. Soil cores were taken at 0 $10,10-20$ and $20-30 \mathrm{~cm}$ depths using a metallic ring $(5 \mathrm{~cm}$ in diameter, $5 \mathrm{~cm}$ in height $)$ and weighed. In the laboratory, they were further oven-dried at $105^{\circ} \mathrm{C}$ for $24 \mathrm{~h}$ and weighted to determine their bulk density. Each soil sample was analyzed for carbon content.

\section{Oil Palm Plantations}

As in the forests, the standing live and dead palms were measured in 1 ha plots. This plot size represents about 13 rows and 12 lines for a 9-m planting density in a triangular design. The plot was established at a minimum distance of $18 \mathrm{~m}$ from the plantation boundary. The height of the palms was measured from the soil surface until the top of the highest frond using a clinometer or a metric tape for small individuals. The height of palms was further adjusted to trunk height for biomass computation (see S4 in Supplemental Material 1). The DBH and trunk height of standing dead palms were also recorded.

All dead fronds decomposing on the ground were counted along three $16 \mathrm{~m} \times 36 \mathrm{~m}$ subplots established about $21 \mathrm{~m}$ apart ( 3 rows apart) within the plot (S3). A 16-m width was chosen to include two inter-rows: one with and one without decomposing fronds. The 36-m length was chosen in order to include three palms within a sampling row. Three fronds per subplot were randomly chosen, cut into small pieces and weighed. Subsamples were freshweighed, oven-dried in the laboratory at $65^{\circ} \mathrm{C}$ until constant mass and weighed. Three replicates each made up of three mixed sub-subsamples from each subplot were taken to determine the carbon content.

Fallen DW, understory, litter and soil were measured similarly as in the forests with some differences in the protocol (S3). Understory and litter were sampled inside the whole surface of one of the three circular plots established in each $16 \mathrm{~m} \times 36 \mathrm{~m}$ subplot. Soil pits were positioned in another circular plot; with one pit located $4.5 \mathrm{~m}$ from the palm in the inter-line where fronds were left to decompose (frond line) and the other one diametrically opposed, in the harvesting line.

\section{Data Analysis}

\section{Composition and Structure of Disturbed Forests}

The floristic composition and structure of forest sites were analyzed using trees with a $\mathrm{DBH} \geq 10$ $\mathrm{cm}$, in accordance with the scientific literature (Phillips and others 2003; Honorio-Coronado and others 2015). The composition was characterized by quantifying the richness, importance and diversity of taxa. Taxa richness was assessed by the density of species, genus and family (Kindt and Coe 2005) with unidentified individuals being discarded from the analysis. We used the species Importance Value Index (IVI) to identify the most ecologically important species. Due to the nested plot design 
and frequency counts being sensitive to sample size (Smith and others 1986), the IVI was calculated separately for trees with a DBH above $30 \mathrm{~cm}$ (inventoried in one 1 ha plot) and trees with a $\mathrm{DBH}$ between 10 and $30 \mathrm{~cm}$ (inventoried in three $16 \mathrm{~m} \times 36 \mathrm{~m}$ subplots). The IVI varies between 0 and 300 and was computed following the equation by Honorio-Coronado and others (2015), as:

$$
\mathrm{IVI}_{\mathrm{i}}=100 \times\left[\frac{\mathrm{Ab_{i }}}{\mathrm{Ab_{ \textrm {t } }}}+\frac{\mathrm{Do}_{\mathrm{i}}}{\mathrm{Do}_{\mathrm{t}}}+\frac{\mathrm{Fr}_{\mathrm{i}}}{\mathrm{Fr}_{\mathrm{t}}}\right]
$$

where i refers to an individual taxon and $t$ to the total, in the corresponding sampling unit; $\mathrm{Ab}$ is the abundance, the number of individuals; Do is the dominance by the stem basal area $\left(\mathrm{m}^{2} \mathrm{ha}^{-1}\right)$; Fr is the frequency, the occurrence of a taxon.

We used Fisher's alpha index to characterize species diversity, a diversity indicator widely applied in Amazonian forests (Gamarra and others 2015; Phillips and others 2003; Honorio-Coronado and others 2015). Diversity indexes allow to combine information on species richness and evenness in a single statistic (Kindt and Coe 2005). The Fisher's alpha index is based on a logarithmic series model built upon species abundance information (Fisher and others 1943). It was calculated separately for trees with $\mathrm{DBH}$ above $30 \mathrm{~cm}$ and trees with a DBH between 10 and $30 \mathrm{~cm}$ using taxa abundance as input for the species matrix in the vegan package of the $\mathrm{R}$ program.

Forest structure parameters included average tree $\mathrm{DBH}$, height, basal area $\left(\mathrm{m}^{2} \mathrm{ha}^{-1}\right)$, volume $\left(\mathrm{m}^{3} \mathrm{ha}^{-1}\right)$ and density $\left(\mathrm{N} \mathrm{ha}^{-1}\right)$ per site. To account for the approximate cone shape of tree stem, volume calculation used a 0.5 form factor considered conservative in disturbed Amazonian forests (Galván and others 2000). Forest structure variables and AGB values for small individuals (DBH $10-30 \mathrm{~cm}$ ) were extrapolated to 1 ha and added to the values for large individuals $(\mathrm{DBH}>30 \mathrm{~cm})$.

\section{Biomass and Carbon Stocks}

In forests, the AGB of trees and the standing DW (kg dry matter: $\mathrm{dm}$ tree $^{-1}$ ) (status D1 and D2) with a DBH $>5 \mathrm{~cm}$ was calculated following the allometric model by Chave and others (2014).

$$
\mathrm{AGB}_{\text {tree }}=0.0673 \times\left[\rho \times \mathrm{DBH}^{2} \times H\right]^{0.976}
$$

where $\rho$ is the wood specific gravity $\left(\mathrm{g} \mathrm{cm}^{-3}\right)$ and $H$ is the tree height $(\mathrm{m})$ which was computed as:

$$
H_{\text {tree }}=e^{\left[0.893-\mathrm{E}+0.760 \times \ln (\mathrm{DBH})-0.0340 \times[\ln (\mathrm{DBH})]^{2}\right]}
$$

Species-specific wood gravity values were obtained from the global wood density database (Zanne and others 2009) and other references (Chave and others 2006; Goodman and others 2014). Whenever species-specific values were not available, a family- or genus-level average was used, and in the absence of family-level values the average wood density of the plot was used (Baker and others 2004). The E factor of environmental stress was obtained from the raster tools provided by Chave and others (2014) and averaged across sites $(-0.075)$.

The mass of standing dead trees of status Dl and D2 was adjusted by subtracting an estimated constant of 2.5 and $15 \%$ of the estimated mass computed from Eq. (2), respectively, to account for the absence of biomass in leaves and small branches (Kauffman and Donato 2012). The mass of standing dead trees of status D3 was calculated as the volume of a cylinder multiplied by the wood specific gravity corrected by a 0.5 form factor (Galván and others 2000).

BGB of standing live trees was computed using the 0.235 root-to-shoot ratio for tropical/subtropical moist forest with less than $125 \mathrm{Mg} \mathrm{dm} \mathrm{ha}{ }^{-1}$ (Mokany and others 2006). The roots of standing dead trees and palms were considered negligible and were not accounted for. The plot-average carbon content of large sound woody debris was used to convert $\mathrm{AGB}, \mathrm{BGB}$ and standing DW estimates to carbon stocks $\left(\mathrm{Mg} \mathrm{C} \mathrm{ha}^{-1}\right)(\mathrm{C}$ content in the range of $41.6-44.8 \%$; see detailed C content data in Supplemental Material 2).

The AGB of palms ( $\mathrm{Mg} \mathrm{dm}$ palm $\left.^{-1}\right)$ was calculated using the allometric equation by Khasanah and others (2015a):

$$
\mathrm{AGB}_{\mathrm{OP}}=0.0923 \times H+0.13333
$$

where $H$ is the height of the palm trunk (m).

Their BGB was estimated using root-to-shoot ratios of 0.61 for young stands (1-6-year old) (Syahrinudin 2005), 0.29 for middle-aged stands (7-19-year old) (Syahrinudin 2005) and 0.19 for older stands ( $>$ 19-year old) (Khalid and others 1999). The mass of standing dead palms was computed as the volume of the palm times the average specific gravity of the plot large sound woody debris class. The AGB, BGB and standing dead palms carbon stocks $\left(\mathrm{Mg} \mathrm{C} \mathrm{ha}^{-1}\right)$ in oil palms were calculated using the plot-average carbon content in large sound woody debris ( $\mathrm{C}$ content in the range of $38.4-45.6 \%$ ).

The volume of fallen DW was computed using the formulas provided by Kauffman and Donato 
(2012). The volume of medium woody debris (2$8 \mathrm{~cm}$ diameter) was calculated as:

$$
\operatorname{Volume}\left(\mathrm{m}^{3} \mathrm{ha}^{-1}\right)=\pi^{2} \times\left[\frac{N_{\mathrm{i}} \times \mathrm{QMD}_{\mathrm{i}}^{2}}{8 \times L}\right]
$$

where $N_{\mathrm{i}}$ is the count of intersecting woody debris pieces, $\mathrm{QMD}_{\mathrm{i}}$ is the quadratic mean diameter of wood pieces in the subplot with QMD $=\sqrt{\left(\Sigma d i^{2}\right) / n}$ and $L$ is the full transect length $(18 \mathrm{~m})$.

The volume of large woody debris was calculated from individual diameter measurements as:

$$
\operatorname{Volume}\left(\mathrm{m}^{3} \mathrm{ha}^{-1}\right)=\pi^{2} \times\left[\frac{d_{1}^{2}+d_{2}^{2}+\cdots+d_{m}^{2}}{8 \times L}\right]
$$

where $d_{1}, d_{2}$ and so on are the diameters of intersecting pieces of large dead wood $(\mathrm{cm})$ and $L$ is the full transect length $(18 \mathrm{~m})$.

The mass of fallen DW in each circular plot $\left(\mathrm{Mg} \mathrm{dm} \mathrm{ha}^{-1}\right)$ was calculated per decay class (medium, large sound, large rotten) as the volume multiplied by its mean specific gravity. The average specific gravity per size class was computed from the ten wood pieces collected in each plot. The mass was converted to a $\mathrm{C}$ stock $(\mathrm{Mg} \mathrm{C} \mathrm{ha-1})$ using the plot $\mathrm{C}$ content specific to the decay classes, that is, medium (in the range of $41.4-46.5 \%$ in forests, $38.7-48.8 \%$ in oil palm), large sound (41.6-44.8\% in forests, $38.4-45.6 \%$ in oil palm) and large rotten $(41.5-45 \%$ in forests, $36.2-46.8 \%$ in oil palm) (Kauffman and Donato 2012).

The mass of fronds $\left(\mathrm{Mg} \mathrm{dm} \mathrm{ha}{ }^{-1}\right)$ in oil palm plantations was computed from the number of fronds counted per subplot and the average dry mass of a frond in the plot. The latter was obtained from the wet mass of the nine fronds measured per plot and the wet-to-dry mass ratio from the three subsamples per plot. C stocks were calculated with the subplot-specific C contents (in the range of 39$44 \%$ ).

The computation of mass and carbon stock in litter and understory followed the same steps as for the fronds. The wet mass measured per subplot was converted to dry mass using the plot-specific wetto-dry mass ratio. The carbon stock was computed from the dry mass using the plot-specific carbon content (ranges between plots for forest understory and litter, and oil palm understory and litter of 37$44 \%$; $24-45 \%$; $23-43 \%$; and $27-41 \%$, respectively).

Soil carbon stocks $\left(\mathrm{Mg} \mathrm{C} \mathrm{ha}^{-1}\right)$ were calculated on a volume basis as:

$$
\mathrm{SCS}=\mathrm{C} \times \mathrm{BD} \times l \times 100
$$

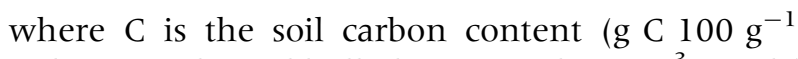
soil); $\mathrm{BD}$ is the soil bulk density $\left(\mathrm{g} \mathrm{dm} \mathrm{cm}^{-3}\right)$; and $l$ is the soil layer thickness $(\mathrm{cm})$

A calculation on a mass basis was not necessary as forest and oil palm plantation soils exhibited similar bulk densities (Hergoualc'h and others 2012; Frazão and others 2013). The C content in soils (in the range of $0.2-3.2 \%$ ) and other pools was determined by dry combustion in a Costech EA $\mathrm{C}-\mathrm{N}$ analyzer at the laboratory of University of Hawaii-Hilo, Hawaii.

\section{Statistics}

Means and standard errors of $\mathrm{C}$ stocks in forest sites were computed by pool using plot replicates, except for the AGB and BGB, which were measured in a single plot. The Gaussian error propagation method by Lo (2005) was used for propagating uncertainties. For addition and subtraction, uncertainties were propagated by quadrature of absolute errors, for multiplication and division propagation was by quadrature of relative errors.

Oil palm C stocks from the different age stands were used to develop models of trend over time and generate time-average carbon stocks over a rotation period. Models were based on plot replicates for all pools except for the AGB, where no replicates were available. Different regression models (exponential, logarithmic, polynomial, among others) were tested for all pools. The best fitted model was chosen based on Akaike Information Criterion (AIC). C stocks were further computed from the models at a yearly time-step over 30 years and averaged to yield the time-average stock. For the frond pile C stock, the model considered no stock accumulation for ages below 3 years, that is, before palms reach maturity, produce fruits and fronds start being cut (Henson 2009b; Oktarita and others 2017). Yearly BGB calculation from AGB estimates used root-to-shoot ratios corresponding to the stand age. Results are displayed with their respective standard errors.

Statistical analysis was performed using the open-source software Infostat (Di Rienzo and others 2018) and R (version 3.3.2), with a probability level of $5 \%$ to test the significance of effects. The distribution of residuals for each variable was evaluated using the Shapiro-Wilk's test. The $t$ test was used to compare two means (for example, disturbed forest vs oil palm plantation) for normally distributed residuals. For multi-comparison, ANOVA and the nonparametric test of Kruskal-Wallis were performed, respectively, on variables with normally and non-normally distributed residuals. 

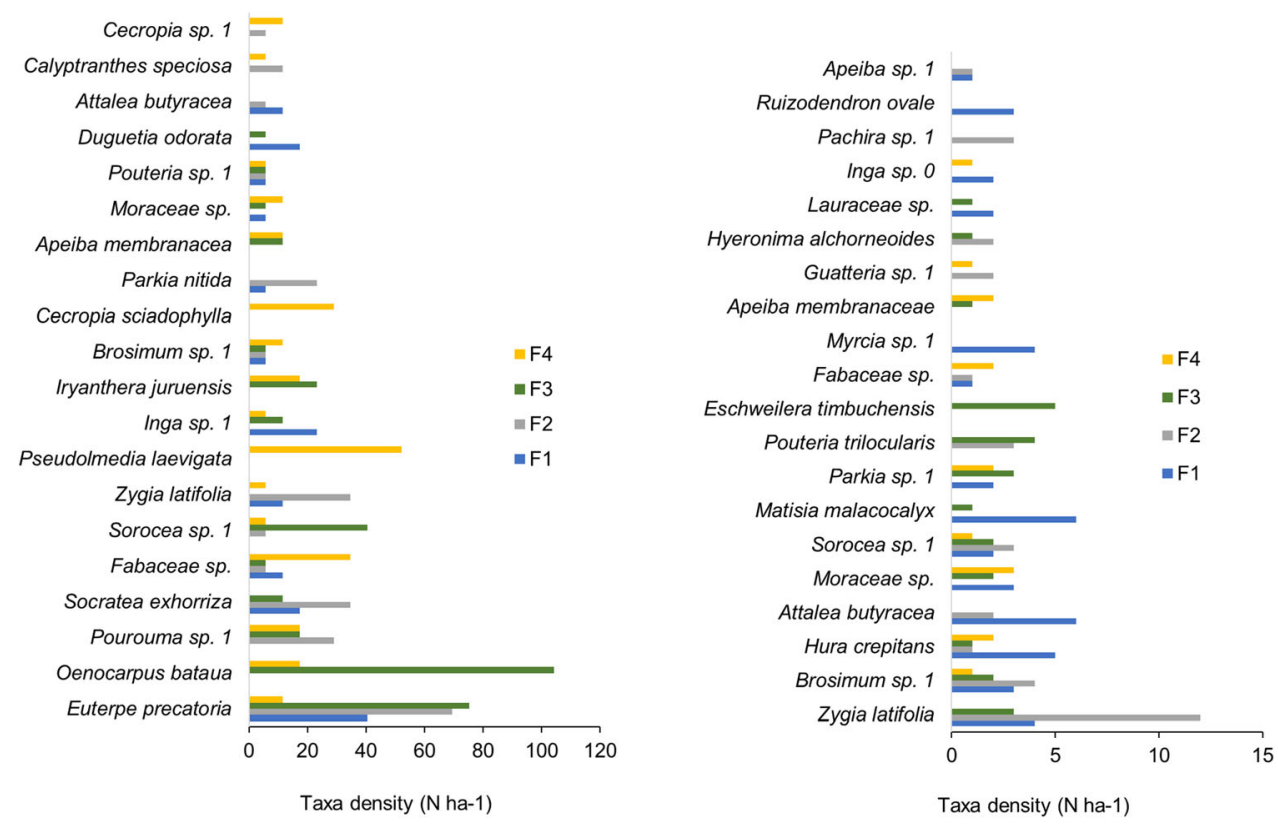

Figure 2. Twenty most abundant taxa in disturbed forest sites (F1, F2, F3, F4) nearby Pucallpa. The analysis considered trees with a diameter at breast height between 10 and $30 \mathrm{~cm}$ (left) and above $30 \mathrm{~cm}$ (right).

\section{RESUlTS}

\section{Composition and Structure of Disturbed Forests}

A total of 573 living trees with a DBH at least $10 \mathrm{~cm}$ were recorded across the four forest sites. Within the 4 ha sampled, we identified 161 taxa, of which 99 were differentiated at species level, 48 at genus level and 13 at family level. According to the analysis of taxa richness (Figure 2), the sites shared similarities in species composition. Shared species for trees with a DBH below $30 \mathrm{~cm}$ included mainly medium- to fast-growing species such as Euterpe precatoria, Oenocarpus bataua, Socratea exorrhiza, Cecropia sciadophylla and Cecropia sp.1. In this size class, there were also wood-valuable species from the families Myristicaceae (Iryanthera juruensis) and Myrtaceae (Calyptranthes speciosa, Myrcia sp. 1) (Gentry 1996; Pennington and others 2004). The sites also harbored large and small trees of species representative of gaps or disturbed forest (Pourouma sp. Zygia latifolia, etc.). Another similitude between sites was the dominance of the Arecaceae family (palm trees), with species such as Euterpe precatoria, Oenocarpus bataua, Socratea exorrhiza and Attalea butyracea ranking among the most abundant. The stands were seemingly homogeneous in terms of species importance with the first five species with highest Importance Value Index (IVI) contributing to more than half of the total IVI per site (S5 in Supplemental Material 1). The average Fisher's alpha of $44.6 \pm 6.6$ (range 31.8-62.3) for the smaller DBH class and $23.3 \pm 7.8$ (range 7.5-45.0) for trees with a $\mathrm{DBH}$ above $30 \mathrm{~cm}$ suggests a low floristic diversity (see S6 in Supplemental Material $1)$.

The distribution of tree diameters showed a classic reverse $J$-shaped curve at all sites, with large trees of DBH greater than $30 \mathrm{~cm}$ being much less abundant than small individuals (Figure 3) as typically found in natural forests. However, the average DBH $(24.3 \pm 2.3 \mathrm{~cm})$, height $(20.1 \pm 1.0 \mathrm{~m})$, basal area $\left(18.7 \pm 1.4 \mathrm{~m}^{2} \mathrm{ha}^{-1}\right)$ and tree density $\left(597 \pm 48.8\right.$ trees $\left.\mathrm{ha}^{-1}\right)$ indicated signs of disturbance. There were some differences among sites with forest $\mathrm{Fl}$ displaying a higher mean DBH $(27.2 \mathrm{~cm})$, height $(21.3 \mathrm{~m})$ and a lower tree density ( 534 trees $\mathrm{ha}^{-1}$ ) in comparison with results at the other sites (S6 in Supplemental Material 1). Also,

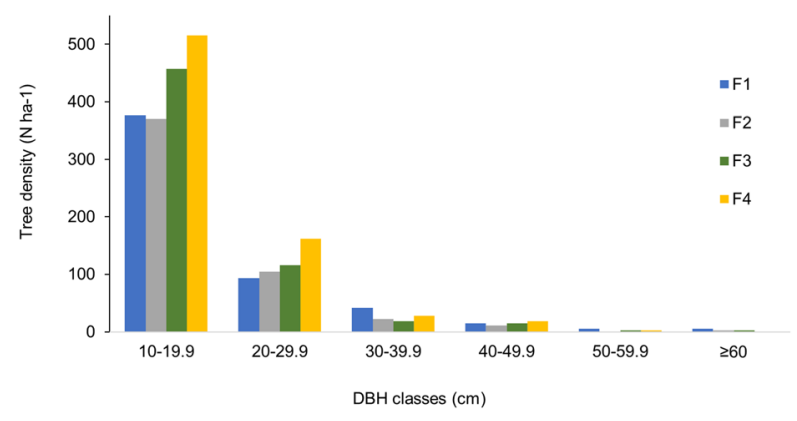

Figure 3. Tree density per diameter at breast height (DBH) class at the disturbed forest sites (F1, F2, F3, F4). 
forest $\mathrm{F} 4$ had the highest basal area $\left(22 \mathrm{~m}^{2} \mathrm{ha}^{-1}\right)$ among sites, as a result of a high density of trees with a DBH below $30 \mathrm{~cm}$ (Figure 3).

\section{Shifts in Structure and Carbon Stocks Along the Oil Palm Plantation Chronosequence}

The height of palms increased with stand age following a logarithmic trend (Figure 4). Planting density was not homogenous across stands. The 15year-old stand was planted at a higher density (211 palms ha ${ }^{-1}$ ) than other stands causing the palms here to grow taller $(12.7 \mathrm{~m})$. Heterogeneity in planting density is characteristic of small- and medium-size plantations not systematically managed according to the standard recommendations.

The $C$ stock in AGB and fronds increased over time, whereas the stock in dead wood, understory and soils presented an inverted trend (Figure 5 and detailed C stocks per site available in S7 of Supplemental Material 1). The litter stock remained steady over time $(p>0.5)$; therefore, no model was developed. As the soil displayed similar bulk density, $\mathrm{C}$ content and $\mathrm{C}$ stock values in the frond line and harvesting path $(p>0.2)$, soil C stocks were not disaggregated by spatial position. For all pools exhibiting a significant trend of increase or decrease in $\mathrm{C}$ stock over time, the best-fit model was logarithmic.

\section{Stocks and Stock Changes Associated with Disturbed Forest Conversion to Smallholder Oil Palm Plantation}

C stocks were similar among disturbed forest sites, except for dead wood which was higher in site F2 $(p=0.0185)$ due to the importance of fallen DW (see detailed C stocks in standing and fallen DW in S7-Supplemental Material 1). Mean carbon stocks

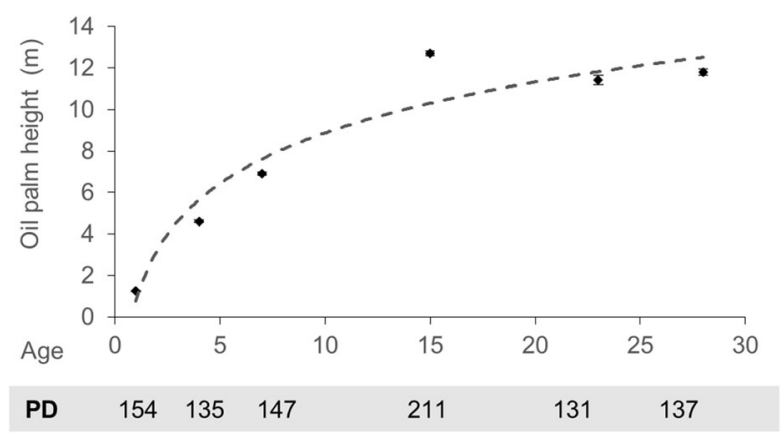

Figure 4. Mean total oil palm height according to stand age (years). Planting density $\left(\mathrm{PD}, \mathrm{N}\right.$ ha $\left.{ }^{-1}\right)$ is displayed at the bottom of the figure. Error bars represent standard error of the mean. in disturbed forests were, for most pools, larger than the highest carbon stock that oil palms could reach over the rotation period (Figure 5). AGB, dead wood and litter had a systematic higher carbon stock in disturbed forests than in oil palm plantations. The understory $C$ stock was similar in forest and one-year old plantation, but the stock decreased with palm age. On the other hand, the soil carbon stock was at the highest in the first years of the oil palm plantations and declined over time until reaching a level similar to the average stock in forest stands.

Ecosystem carbon stock in disturbed forests was almost twice the 30-year time-average carbon stock in oil palm plantations (Table 2). In both land-use types, C stocks were mainly allocated to AGB and soil, while litter and understory were the least contributing pools. Carbon stocks of oil palm plantations were in general significantly lower than stocks in disturbed forests, except for understory $(p=0.0826)$ and soil $(p=0.0227)$. The conversion from disturbed forest to oil palm plantation resulted in a carbon stock loss of $62.7 \pm 6.1 \mathrm{Mg} \mathrm{C} \mathrm{ha}^{-1}$ over 30 years.

\section{Discussion}

\section{Effects of Disturbance on Forest Composition, Structure and C Stocks}

The floristic composition and structure of the forests in the different sites reflected their disturbance. The sites harbored pioneer species found in secondary forests (Cecropia sp., Inga sp.) and species commonly growing in gaps (Pourouma bicolor, Pourouma sp.) (Ríos Trigoso 1990; Estrada Tuesta 1993; Gentry 1996; Pennington and others 2004), predominantly within the smaller classes. At the same time, they were home of species typical of primary lowland forest (for example, Oenocarpus bataua, Socratea exorrhiza, Apeiba membranacea, Pseudolmedia laevigata, Iryanthera juruensis, Pouteria trilocularis, Matisia malacocalyx, and Cecropia sciadophylla) (Gamarra and others 2015), within small and large trees. Compared with inventories in lowland undisturbed forest of Ucayali, there was a clear absence of some important commercial species such as Dipteryx odorata (shihuahuaco) or Ormosia amazonica (huayruro) (Oficina Nacional de Evaluacion de Recursos Naturales 1983, Gamarra and others 2015), probably as a consequence of past logging activities. The sites presented a Fisher's alpha index lower than values found in undisturbed floodplain forests of Ucayali (105.8 in the study by Gamarra and others (2015)) and undis- 

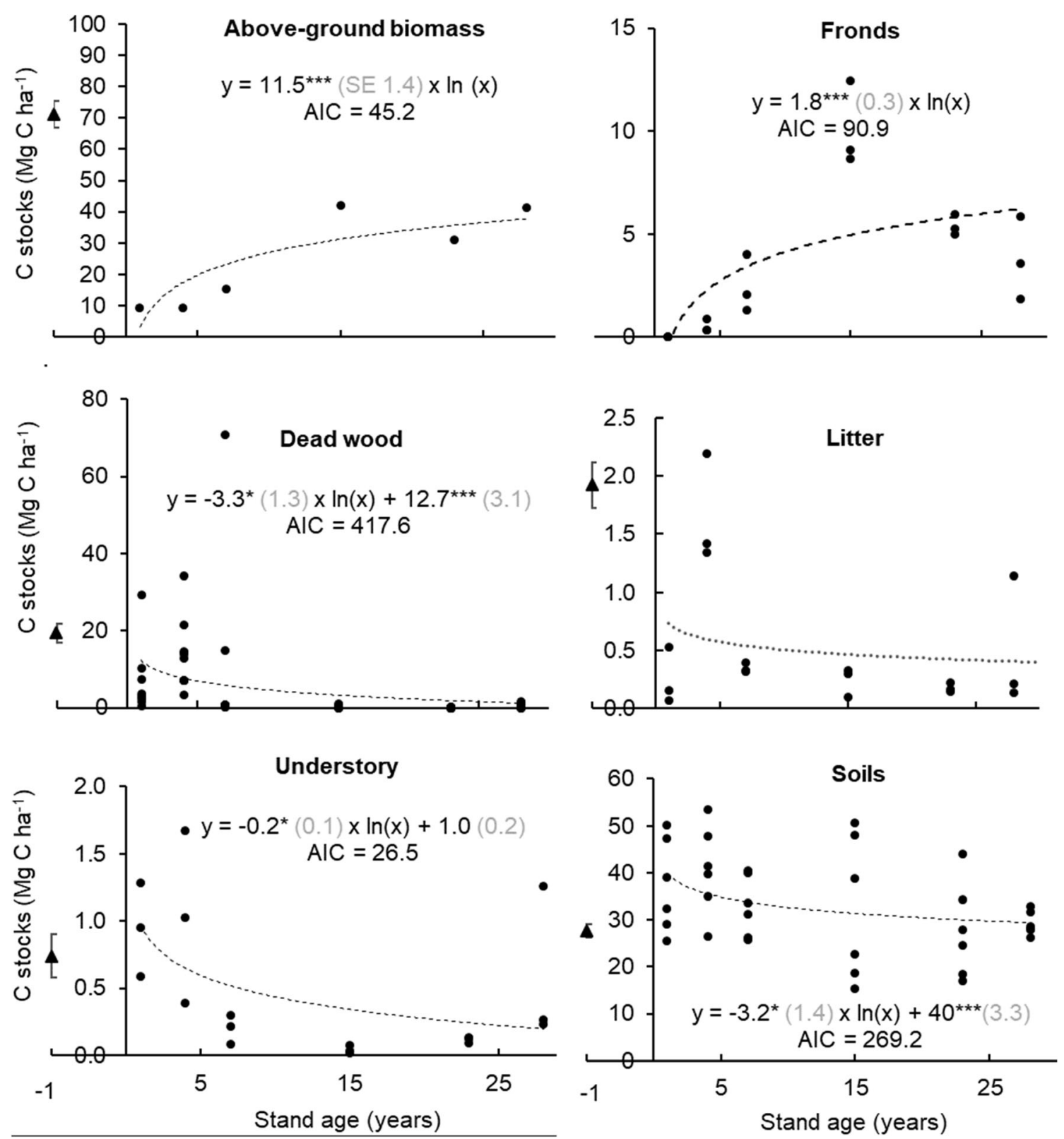

Figure 5. Models of carbon trend over a 30-year oil palm rotation period built upon replicate measurements (-) at the study sites (OP1Y, OP4Y, OP7Y, OP15Y, OP23Y, OP28Y). No model is displayed for the litter which did not exhibit a significant trend over time. Average $\mathrm{C}$ stocks $(\mathbf{\Delta})$ and standard error in disturbed forests are displayed as a reference. The level of significance of the model parameters are indicated by ${ }^{*}(p<0.05),{ }^{* *}(p<0.01)$ and ${ }^{* * *}(p<0.001)$. Grey numbers in parenthesis are the standard error of the model parameters. AIC stands for Akaike information criterion.

turbed forests in the Peruvian Amazonian regions of Loreto and Madre de Dios $(224 \pm 39.6$ and $78 \pm 23.4$, respectively; in the study by Phillips and others (2003). Notwithstanding, comparison of diversity indices across subsets of different sampling intensities, spatial scale, or across different regions should be made cautiously (Kindt and Coe 2005; Duque and others 2017). Alpha diversity increases from east to west in Amazonia, and from south to north in the western part (Wittmann and others
2006), but biodiversity is also linked with stand age of secondary forests (Wittmann and others 2006), negatively correlates with inundation regimes (Nebel and others 2001; Wittmann and others 2006; Gamarra and others 2015; Honorio-Coronado and others 2015) and is associated with soil factors (such as nutrients, texture, $\mathrm{pH}$ or drainage) (Phillips and others 2003; Gamarra and others 2015). 
Table 2. Summary Information of Carbon Stocks per C Pool and Land Use

\begin{tabular}{|c|c|c|c|c|c|c|c|}
\hline \multirow[t]{2}{*}{ Pool } & \multicolumn{3}{|c|}{ Oil palm plantation } & \multicolumn{3}{|c|}{ Disturbed forest } & \multirow{2}{*}{$\begin{array}{l}\text { Undisturbed Amazon forest } \\
\text { Mean } \pm \text { SE }\end{array}$} \\
\hline & $n$ & Mean & SE & $n$ & Mean & SE & \\
\hline AGB & 30 & $28.6^{\mathrm{a}}$ & 1.8 & 4 & $71.3^{\mathrm{b}}$ & 4.2 & $113^{\mathrm{i}}$ \\
\hline BGB & 30 & $9.0^{\mathrm{a}}$ & 0.2 & 4 & $19.8^{\mathrm{b}}$ & 2.8 & - \\
\hline Understory & 30 & 0.4 & 0.04 & 4 & 0.7 & 0.2 & - \\
\hline Dead wood & 30 & $4.4^{\mathrm{a}}$ & 0.5 & 4 & $19.5^{\mathrm{b}}$ & 2.5 & $8.3 \pm 0.6^{\mathrm{ii}}$ \\
\hline Fronds & 30 & 4.5 & 0.3 & - & n.a. & n.a. & - \\
\hline Litter & 6 & $0.4^{\mathrm{a}}$ & 0.1 & 4 & $1.9^{\mathrm{b}}$ & 0.2 & - \\
\hline Phytomass & 6 & $46.1^{\mathrm{a}}$ & 1.9 & 5 & $113.2^{\mathrm{b}}$ & 5.6 & - \\
\hline Soil & 30 & $32.1^{\mathrm{b}}$ & 0.5 & 4 & $27.7^{\mathrm{a}}$ & 1.4 & $30.2 \pm 1.7^{\mathrm{iii}}$ \\
\hline Ecosystem & 7 & $78.2^{\mathrm{a}}$ & 2.0 & 6 & $140.9^{\mathrm{b}}$ & 5.8 & - \\
\hline
\end{tabular}

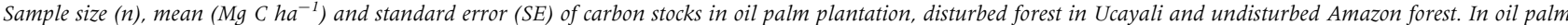
plantations, carbon stocks are the average of values modeled over a 30-year rotation for all pools except for litter which stocks were computed from the six sampled plots. AGB and $B G B$ : Above-and below-ground biomass in standing palms or trees with a diameter at breast height $>5 \mathrm{~cm}$. Letters a and $b$ indicate a significant difference between land uses $(p<0.05)$. Mean values in undisturbed Amazon forest from the literature are displayed in the last column, based on studies from ${ }^{i}$ Southeast Peruvian lowland forests (137.3 \pm 5.3; Pallqui and others 2014); Northeast Peruvian flooded forests (90 \pm 12.8 ; Honorio-Coronado and others 2015) and Ucayali floodplain forest (112.1; Gamarra and others 2015). Values for dead wood and soil come from ${ }^{i i}$ Southeast Peruvian floodplain forest (Baker and others 2007) and ${ }^{\text {iii }}$ Northwest Brazilian native forest in the soil top $30 \mathrm{~cm}$ (Frazão and others 2013). Literature biomass results were converted to a C stock using the IPCC default 47\% C content (Aalde and others 2006).

Degradation also affected forest structure. The inverted "J" DBH distribution with most individuals confined to the smallest DBH classes is characteristic of natural lowland forests (Gamarra and others 2015; Honorio-Coronado and others 2015). This tendency was exacerbated at the disturbed sites which displayed low densities of large trees. The mean basal area at the sites was less than what has been found in undisturbed forests in southeast Peruvian Amazonia $\left(29 \mathrm{~m}^{2} \mathrm{ha}^{-1}\right.$; Baker and others 2004); in Ucayali $\left(29.7 \mathrm{~m}^{2} \mathrm{ha}^{-1}\right.$; Tournon and Riva 2001) or in the northwest Peruvian Amazonian floodplains (22.6-28.8 $\mathrm{m}^{2} \mathrm{ha}^{-1}$; Nebel and others $2001)$. It was similar to the basal area in a 20 -yearold secondary forest in Ucayali $\left(18.9 \mathrm{~m}^{2} \mathrm{ha}^{-1}\right)$ (Tournon and Riva 2001). Our experimental design assumed the four forest sites to be homogeneous replicates representative of the remnant forest landscape of Campo Verde, Ucayali. However, there were some differences in structural parameters among sites (Figure 3), probably due to varying intensities in land use. But their floristic composition was similar, despite site F4 being located at a slightly higher level less exposed to flooding than the other sites (Gobierno Regional de Ucayali 2015). All sites harbored species typical of both flooded or periodically flooded lands (Euterpe precatoria, Zygia latifolia, Parkia nitida) and also species present in terra firme forest (Pourouma sp.l, Socratea exorrhiza, etc.) (Gentry 1996; Pennington and others 2004; Esquivel-Muelbert and others 2019).

As expected, the AGB C stock of degraded forests was almost $40 \%$ less than the average value of undisturbed Peruvian Amazonian forests from the literature (Table 2). The $\mathrm{C}$ stock in $\mathrm{AGB}$ (71.3 $\pm 4.2 \mathrm{Mg} \mathrm{C} \mathrm{ha}^{-1}$; Table 2) was comparable to results found in a logged forest in the Brazilian state of Para $\left(80 \mathrm{Mg} \mathrm{C} \mathrm{ha}^{-1}\right)$ (Ferreira and others 2018), in old secondary forests in Mexico $\left(89 \mathrm{Mg} \mathrm{C} \mathrm{ha}{ }^{-1}\right.$ ) (Orihuela-Belmonte and others 2013) or in logged forests in Borneo $\left(83.2 \pm 6.8 \mathrm{Mg} \mathrm{C} \mathrm{ha}^{-1}\right)$ (Berry and others 2010). It was much lower, though, than the 121.5 Mg C ha ${ }^{-1}$ stock reported by Barbarán García (2000) in logged forests of Ucayali. The AGB was the pool contributing the most $(50 \%)$ to ecosystem C stock; followed by the soil and necromass (dead wood plus litter). In their review, Palace and others (2012) found a high variation in necromass among tropical forests and a global tendency for the necromass to biomass relationship to follow a concave quadratic function linked to the degradation level. With low AGB and high necromass stock (Table 2), the sites classify as highly disturbed along the tendency described by Palace and others (2012). Lastly, the soil top $30-\mathrm{cm} \mathrm{C}$ stock was much higher than that measured by Meza Doza (2016) in Ucayali forest concessions $\left(16.21 \pm 1.6 \mathrm{Mg} \mathrm{C} \mathrm{ha}^{-1}\right)$ located at Litosol-Regosol and Nitosol-Luvisol soils (Gobierno Regional de Ucayali 2016c), but similar to results by Frazão and others (2013) in Brazilian native forests (Table 2). 


\section{Stocks in Oil Palm Plantation}

Our results show that carbon stocks in all pools, except for the litter, increased or decreased logarithmically over time during the first rotation of a palm plantation. A range of regression types has been used in the literature for palm AGB growth, including linear (Khasanah and others 2015a and Quezada and others 2019), power (Germer and Sauerborn 2008; Khasanah and others 2015a), logarithmic (Syahrinudin 2005) or polynomial models (Henson 2009a). Nonlinear models capture better the accumulation of palm biomass, with initial fast growth slowing down toward the end of the rotation. As noted by Henson (2017), biomass decline is also linked to death of old palms or failure of frond production to compensate for loss from frond pruning and fruit harvesting, among other factors. Our accumulation curve was slightly above the curve by Germer and Sauerborn (2008) generated from data collected across the tropics but systematically below all models developed from plantations in Indonesia (Syahrinudin 2005; Khasanah and others 2015a), managed either by smallholders or large-scale producers (Figure 6). Slower growth may be associated with less intensive management by Peruvian smallholders as compared to Indonesian producers as suggested by the low average yield in Peru (Pinzon 2018). The increase in frond pile $\mathrm{C}$ stock over time followed a pattern similar to, but slightly above, predictions by the OPROSIM model (Henson 2009b; large frond size option). Young palm stands held a large dead wood C stock stemming from deforestation which decomposed gradually as the plantation aged, as also found by Khasanah and others (2015a). The stock in litter remained steady over time in agreement with results by Khasanah and others (2015a), whereas Syahrinudin (2005) found a small linear increase with palm age. Leguminous creepers such as Pueraria montana (called kudzu in Peru) are usually sown at the time of planting palms to prevent soil erosion and maintain soil fertility (Corley and Tinker 2003). Other creepers and climbers may also establish themselves naturally. As the canopy of palms closed and intercepted light, the $\mathrm{C}$ stock in the understory decreases. The reduction of combined understory and litter pools reported by Henson (2009b) also followed a logarithmic tendency over time, though the maximum stock for young stands $\left(5 \mathrm{Mg} \mathrm{C} \mathrm{ha}^{-1}\right)$ was more than threefold the highest stocks simulated here (Figure 5). The soil C stock declined sharply by $27 \%$ over 30 years; much faster and importantly than the insignificant trend found by Khasanah and others (2015b) (Figure 6). This discrepancy may be ascribed to methodological divergence between our study and the one by Khasanah and others (2015b), which pulled together results from plantations on different soil type, with contrasting climate and varying management types.

Comparisons of time-averaged ecosystem C stock in oil palm with assessments from the literature are complicated given differences with regard to the
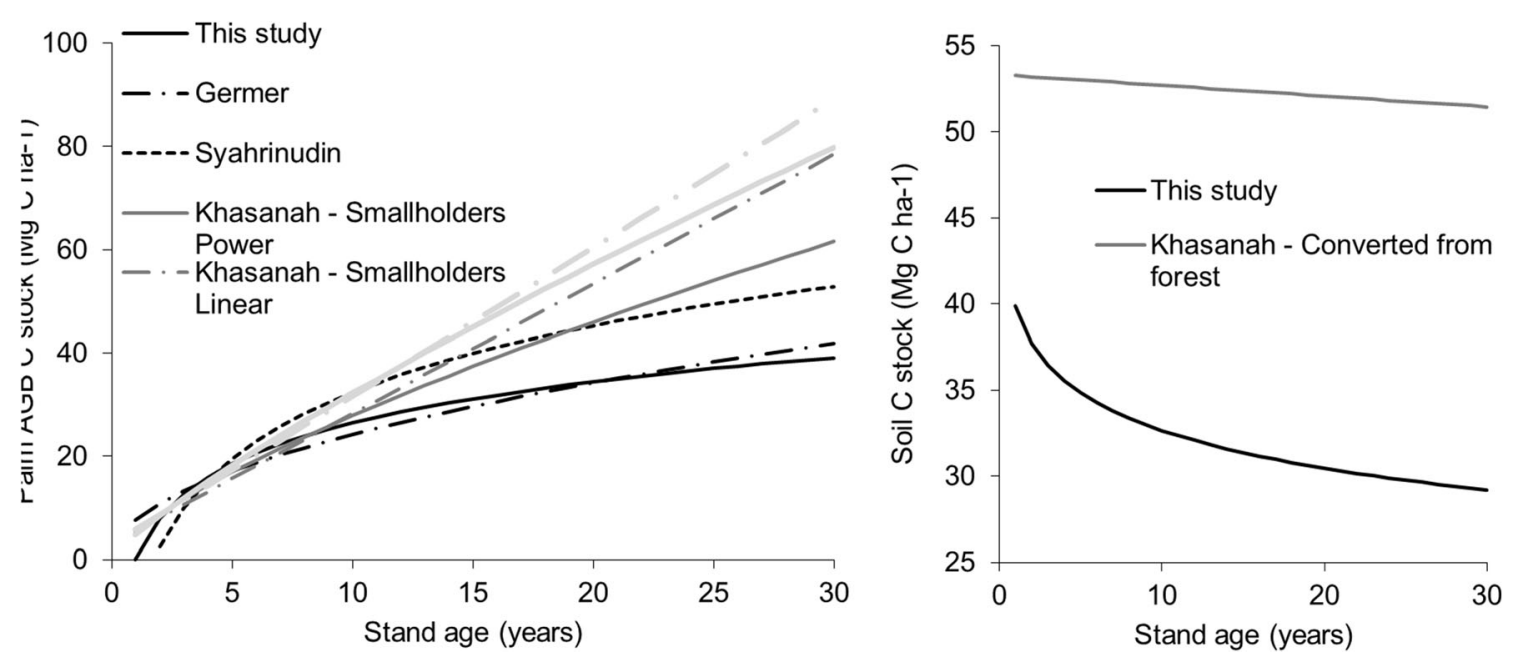

Figure 6. Left panel presents palm above-ground biomass (AGB) C stock growth curves from this study (black solid line) and the studies by Germer and Sauerborn (2008) (black dashed-dotted line), Syahrinudin (2005) (black dotted line), and Khasanah and others (2015a) for smallholders using power (dark gray solid line) and linear models (dark gray dashed-dotted line) and for large-scale producers using power (light gray solid line) and linear models (light gray dashed-dotted line). Right panel shows soil C stock $(0-30 \mathrm{~cm})$ decline with stand age from this study (black solid line) and the study by Khasanah and others (2015b) for plantations converted from forest (dark gray solid line). 
duration of the rotation cycle or the pools accounted for between the publications. For instance, Germer and Sauerborn (2008) and Khasanah and others $(2015 a, b)$ used a 25 -year rotation time, while a 30-year time was applied by Henson (2009b). Here, we considered a 30-year rotation cycle to be representative of practices by Peruvian smallholders. Furthermore, the ecosystem timeaveraged stock by Germer and Sauerborn (2008) reported palm AGB, BGB and understory; Khasanah and others (2015a) included palm AGB, understory, dead wood and litter (including fronds); and Henson (2009b) incorporated palm $\mathrm{AGB}$ and BGB combined, understory (including litter), fronds and additional minor pools (shed frond base and male inflorescence piles). Our results were below the time-averaged palm AGB plus BGB stocks by Henson (2009b) from the OPRODSIM model for large fronds and by Quezada and others (47.4 and $49.5 \pm 1.5 \mathrm{MgC} \mathrm{ha}^{-1}$, respectively). Likewise, they were below the understory plus litter stocks obtained by Henson (2009b) (1.3 Mg C ha-1), but slightly above for fronds (4.1 $\mathrm{Mg} \mathrm{C} \mathrm{ha}^{-1}$ ). The $9-10 \%$ contribution of fronds to phytomass stocks from our and Henson (2009b) research contrasts with the low result reported by Khasanah and others (2015a) ( $1 \mathrm{Mg} \mathrm{C} \mathrm{ha}^{-1}$ in litter plus fronds). In the latter, fronds were inventoried in $0.5 \times 0.5 \mathrm{~m}$ frames placed in four management zones (weeded circle, inter-row, frond pile and harvest paths) around ten palms. The small size of frames may have biased the estimate by accounting mainly for leaflets and rachis and underestimating leaf base and petiole. The time-averaged $C$ stock in the soil top $30 \mathrm{~cm}$ was very similar to values reported by Frazão and others (2013) in Oxisols from the Brazilian Amazonia planted with 4-, 8- and 25-year-old oil palms. Unlike findings by Frazão and others (2013) and Khasanah and others (2015b), who observed higher soil $\mathrm{C}$ stock in the frond pile than in the harvest path, our results showed no difference between the two spatial positions.

\section{Carbon Stock Losses from Forest Conversion to Oil Palm Plantation}

Most of the research that evaluated C stock losses from forest conversion to oil palm has been conducted in Southeast Asia and has essentially focused on primary forest. For instance, Germer and Sauerborn (2008) reported a loss of $176 \pm 98 \mathrm{Mg} \mathrm{C}^{-1}$ including as pools palm AGB, BGB, understory and soil, while Guillaume and others (2018) estimated a very similar value of
$174 \pm 13 \mathrm{Mg} \mathrm{C} \mathrm{ha}^{-1}$ for losses from AGB, BGB and soil. Our ecosystem stock loss from disturbed forest conversion to oil palm $(62.7 \pm 6.1 \mathrm{Mg} \mathrm{C}$ ha $\left.{ }^{1}\right)$ was much smaller than these estimates on the account of less biomass in disturbed forest than in undisturbed forest and also lower average biomass in tropical rainforests of South America as compared to Asia (Avitabile and others 2016). According to Austin and others (2017), most oil palmdriven forest loss during 2005-2015 in Indonesia occurred in disturbed $(95 \%)$ rather than in undisturbed $(5 \%)$ forest. In Ucayali, the studies by Gutiérrez-Vélez and others (2011) and Glinskis and Gutiérrez-Vélez (2019) show a ratio of disturbed forest: undisturbed forest of oil palm-driven deforestation of $45 \%$ : $55 \%$ in $2000-2010$ and $31 \%$ : $69 \%$ in 2010-2016. These results highlight the importance of oil palm expansion into forest and the need to better characterize $C$ losses from forest to oil palm conversion, considering the disturbance status of the forest. Future experiments could also disaggregate degraded forests into residual logged forests and secondary forests and take into consideration management intensity in oil palm plantation which can strongly influence the timeaveraged C stock. Although our results demonstrated that forest to oil palm conversion reflected a C debt at the level of the ecosystem and for most pools, an opposite pattern was found for the soil. The conversion led to a small increase in soil $\mathrm{C}$ stock of $4.4 \mathrm{Mg} \mathrm{C} \mathrm{ha}^{-1}$ very similar to the result of 4.7 $\mathrm{Mg} \mathrm{C} \mathrm{ha}^{-1}$ by Frazão and others (2013) for a 25-year-old plantation converted from a native Amazonian rainforest in Brazil. In contrast, Khasanah and others (2015b) found no change following conversion in Indonesia, while van Straaten and others (2015) measured high soil C stock losses in the top $30 \mathrm{~cm}$ of 14,16 and $10 \mathrm{Mg} \mathrm{C} \mathrm{ha}^{-1}$ from conversion of undisturbed forest in Indonesia, Cameroon and Peru, respectively. These discrepancies may be linked to differences in methods (for example, accounting or not accounting for temporal dynamics of soil $\mathrm{C}$ stocks over the rotation period), practices (slash-and-burn following deforestation and plantation management) or soil properties. At our sites, the original soil $\mathrm{C}$ stock in the disturbed forest of $32.1 \mathrm{Mg} \mathrm{C} \mathrm{ha}{ }^{-1}$ increased to $40 \mathrm{Mg} \mathrm{C} \mathrm{ha}{ }^{-1}$ one year after planting the palms and thereafter declined steadily back to the forest level (Figure 5). A reasonable explanation for this pattern is the decomposition of the high above and below-ground organic matter inputs stemming from slashing and burning the forest. This hypothesis is supported by the temporal trend of dead wood stock which was high at the beginning 
of the rotation and reduced over time. A better understanding of soil carbon dynamics in the converted land would require assessing how decomposition processes in necromass pools may contribute to soil organic matter.

\section{Conclusions}

Peru has set as an objective to increase oil palm production to satisfy the national demand and supply the international market. Most local stakeholders have pledged for sustainability and no deforestation of primary forest, by prioritizing the expansion of the crop over degraded lands. However, the definition of such degraded lands remains unclear and could eventually include disturbed forest. Results from this study showed that disturbed forests retain a large proportion of original above-ground $\mathrm{C}$ stocks reaching as much as $60 \%$ of the stock in undisturbed forests reported in the literature. Our research also demonstrates that the ecosystem carbon loss resulting from converting disturbed forests into oil palm plantations is high; hereby supporting the idea that from a carbon perspective oil palm development should be directed to degraded lands such as abandoned pastures or shrub-lands. We found that the growth curve of palm above-ground biomass in Peruvian medium and smallholder plantations was below that of Indonesian plantations. This finding should be verified in other regions of the country to test whether our results may apply at a national scale. More generally, there is a need for more research across the tropics and within tropical regions on $\mathrm{C}$ losses associated with conversion of forest to oil palm plantation, considering forest status (undisturbed, disturbed) and oil palm plantation management (industrial, less intensive).

\section{ACKNOWLEDGEMENTS}

This research is part of CIFOR's Global Comparative Study on REDD+ (www.cifor.org/gcs). The funding partners that have supported this research include the Norwegian Agency for Development Cooperation (Norad), the International Climate Initiative (IKI) of the German Federal Ministry for Environment, Nature Conservation and Nuclear Safety (BMU) and the CGIAR Research Program on Forests, Trees and Agroforestry (CRP-FTA) with financial support from the CGIAR Fund Donors. The study was also conducted as part of a master thesis undertaken at the Institute of International Forestry and Forest Products at the Technische Universität Dresden, Germany, with the financial support from the German Academic Exchange Service (DAAD). The authors are very thankful to Nicole Mitidieri, Marcella Dionisio and Isaac RiosPerez for coordination of and contribution to the field work; Diego García from the Research Institute of the Peruvian Amazonia (IIAP) and Aoife Bennett for helping with site selection; Marcella Dionisio for compiling the wood density data; Ricardo Zárate Gómez (IIAP) for his excellent support in identification of forest species; and all field assistants, including Manuel, Hugo Tapullima, and Armando Vargas Melendes, for their strong commitment. We would also like to thank the COCEPU oil palm association of Ucayali as well as all medium and smallholders who let access to their lands for this research and provided detailed information on management practices in their plantations; in particular Max Gamarra, Victor Lopez and Sandro who intensively contributed to data collection. Finally, we also are very grateful to the two anonymous reviewers and the editor of the journal for their constructive comments on the manuscript.

\section{OPEN ACCESS}

This article is licensed under a Creative Commons Attribution 4.0 International License, which permits use, sharing, adaptation, distribution and reproduction in any medium or format, as long as you give appropriate credit to the original author(s) and the source, provide a link to the Creative Commons licence, and indicate if changes were made. The images or other third party material in this article are included in the article's Creative Commons licence, unless indicated otherwise in a credit line to the material. If material is not included in the article's Creative Commons licence and your intended use is not permitted by statutory regulation or exceeds the permitted use, you will need to obtain permission directly from the copyright holder. To view a copy of this licence, visit $h$ ttp://creativecommons.org/licenses/by/4.0/.

\section{REFERENCES}

Aalde H, Gonzalez P, Gytarsky M, Krug T, Kurz WA, Ogle S, Raison J, Schoene D, Ravindranath NH, Elhassan NG, Heath LS, Higuchi N, Kainja S, Matsumoto M, Sanz Sánchez MJ, Somogyi Z. 2006. Chapter 4: forest land. In: Eggleston S, Buendía L, Miwa K, Ngara T, Tanabe K (Eds.). IPCC. 2006 IPCC guidelines for national greenhouse gas inventories, Prepared by the National Greenhouse Gas Inventories Programme. Volume 4 (Agriculture, Forestry and other Land Use). IGES, Hayama, JP. pp 679.

Alegre J, Arévalo L, Ricse A. 2003. Reservas de carbono según el uso de la tierra en dos sitios de la Amazonía Peruana. In: Agroforestería para la producción animal en América Latina II: 
Memorias de la Segunda Conferencia Electrónica. Estudio FAO Producción y Sanidad Animal. Rome: FAO. http://ww w.fao.org/3/Y4435S/y4435s00.htm\#Contents.

Alva Vásquez J, Lombardi I. 2000. Impacto de los patrones de uso de la tierra sobre los bosques secundarios de la zona de Pucallpa, Perú. Revista Forestal del Perú XXIII:3-22.

Austin KG, Mosnier A, Pirker J, McCallum I, Fritz S, Kasibhatla PS. 2017. Shifting patterns of oil palm driven deforestation in Indonesia and implications for zero-deforestation commitments. Land Use Policy 69:41-8.

Avitabile V, Herold M, Heuvelink GBM, Lewis SL, Phillips OL, Asner GP, Armston J, Ashton PS, Banin L, Bayol N, Berry NJ, Boeckx P, de Jong BHJ, DeVries B, Girardin CAJ, Kearsley E, Lindsell JA, Lopez-Gonzalez G, Lucas R, Malhi Y, Morel A, Mitchard ETA, Nagy L, Qie L, Quinones MJ, Ryan CM, Ferry SJW, Sunderland T, Laurin GV, Gatti RC, Valentini R, Verbeeck $\mathrm{H}$, Wijaya A, Willcock S. 2016. An integrated pantropical biomass map using multiple reference datasets. Glob Change Biol 22:1406-20.

Baker TR, Phillips OL, Malhi Y, Almeida S, Arroyo L, Fiore AD, Erwin T, Killeen TJ, Laurance SG, Laurance WF, Lewis SL, Lloyd J, Monteagudo A, Neill DA, Patiño S, Pitman NCA, Silva JNM, Martínez RV. 2004. Variation in wood density determines spatial patterns inAmazonian forest biomass. Glob Change Biol 10:545-62.

Baker TR, Honorio Coronado EN, Phillips OL, Martin J, van der Heijden GMF, Garcia M, Silva Espejo J. 2007. Low stocks of coarse woody debris in a southwest Amazonian forest. Oecologia 152:495-504.

Barbarán García JE. 2000. Cuantificación de biomasa y carbono en los principales sistemas de uso de suelo en Campo Verde, Pucallpa.

Barrantes R, Borasino E, Glave M, La Rosa M, Vergara K. 2016. De la Amazonia su palma: aportes a la gestión territorial en la región Loreto. GRADE.

Berry NJ, Phillips OL, Lewis SL, Hill JK, Edwards DP, Tawatao NB, Ahmad N, Magintan D, Khen CV, Maryati M, Ong RC, Hamer KC. 2010. The high value of logged tropical forests: lessons from northern Borneo. Biodivers Conserv 19:985-97.

Blois JL, Williams JW, Fitzpatrick MC, Jackson ST, Ferrier S. 2013. Space can substitute for time in predicting climatechange effects on biodiversity. Proc Natl Acad Sci 110:9374-9.

Chase LDC, Henson IE. 2010. A detailed greenhouse gas budget for palm oil production. Int J Agric Sustain 8:199-214.

Chave J, Muller-Landau HC, Baker TR, Easdale TA, ter Steege H, Webb CO. 2006. Regional and Phylogenetic variation of wood density across 2456 Neotropical tree species. Ecol Appl $16: 2356-67$.

Chave J, Réjou-Méchain M, Búrquez A, Chidumayo E, Colgan MS, Delitti WBC, Duque A, Eid T, Fearnside PM, Goodman RC, Henry M, Martínez-Yrízar A, Mugasha WA, Muller-Landau HC, Mencuccini M, Nelson BW, Ngomanda A, Nogueira EM, Ortiz-Malavassi E, Pélissier R, Ploton P, Ryan CM, Saldarriaga JG, Vieilledent G. 2014. Improved allometric models to estimate the aboveground biomass of tropical trees. Glob Change Biol 20:3177-90.

Corley RHV, Tinker PB, editors. 2003. The oil palm. Oxford: Wiley.

Dammert J. 2016. Promoción y regulación ambiental de la palma aceitera en el Perú: aspectos legales e institucionales. In: Fort $\mathrm{R}$, Borasino E, editors. Agroindustria en la Amazonía: posibilidades para el desarrollo inclusivo y sostenible de la palma aceitera en el Perú. GRADE. pp 69-102.
Di Rienzo JA, Casanoves F, Balzarini MG, Gonzalez L, Tablada M, Robledo CW. InfoStat versión 2018. InfoStat Group, Facultad de Ciencias Agropecuarias, Universidad Nacional de Córdoba, Argentina.

Duque A, Muller-Landau HC, Valencia R, Cardenas D, Davies S, de Oliveira A, Pérez ÁJ, Romero-Saltos H, Vicentini A. 2017. Insights into regional patterns of Amazonian forest structure, diversity, and dominance from three large terra-firme forest dynamics plots. Biodivers Conserv 26:669-86.

Esquivel-Muelbert A, Baker TR, Dexter KG, Lewis SL, Brienen RJW, Feldpausch TR, Lloyd J, Monteagudo-Mendoza A, Arroyo L, Álvarez-Dávila E, Higuchi N, Marimon BS, MarimonJunior BH, Silveira M, Vilanova E, Gloor E, Malhi Y, Chave J, Barlow J, Bonal D, Cardozo ND, Erwin T, Fauset S, Hérault B, Laurance S, Poorter L, Qie L, Stahl C, Sullivan MJP, ter Steege H, Vos VA, Zuidema PA, Almeida E, de Oliveira EA, Andrade A, Vieira SA, Aragão L, Araujo-Murakami A, Arets E, Aymard CGA, Baraloto C, Camargo PB, Barroso JG, Bongers F, Boot R, Camargo JL, Castro W, Moscoso VC, Comiskey J, Valverde FC, da Costa ACL, del Aguila Pasquel J, Fiore AD, Duque LF, Elias F, Engel J, Llampazo GF, Galbraith D, Fernández RH, Coronado EH, Hubau W, Jimenez-Rojas E, Lima AJN, Umetsu RK, Laurance W, Lopez-Gonzalez G, Lovejoy T, Cruz OAM, Morandi PS, Neill D, Vargas PN, Camacho NCP, Gutierrez AP, Pardo G, Peacock J, Peña-Claros M, Peñuela-Mora MC, Petronelli P, Pickavance GC, Pitman N, Prieto A, Quesada C, Ramírez-Angulo H, Réjou-Méchain M, Correa ZR, Roopsind A, Rudas A, Salomão R, Silva N, Espejo JS, Singh J, Stropp J, Terborgh J, Thomas R, Toledo M, Torres-Lezama A, Gamarra LV, van de Meer PJ, and others 2019. Compositional response of Amazon forests to climate change. Global Change Biology 25:39-56.

Estrada Tuesta ZE. 1993. Comportamiento de la regeneración natural de especies arbóreas en diversos tipos de pasturas de la zona de Pucallpa.

Ferreira J, Lennox GD, Gardner TA, Thomson JR, Berenguer E, Lees AC, Mac Nally R, Aragão LEOC, Ferraz SFB, Louzada J, Moura NG, Oliveira VHF, Pardini R, Solar RRC, Vieira ICG, Barlow J. 2018. Carbon-focused conservation may fail to protect the most biodiverse tropical forests. Nat Clim Change 8:744-9.

Fisher RA, Steven Corbet A, Williams CB. 1943. The relation between the number of species and the number of individuals in a random sample of an animal population. J Anim Ecol 12:42-54.

Frazão LA, Paustian K, Pellegrino Cerri CE, Cerri CC. 2013. Soil carbon stocks and changes after oil palm introduction in the Brazilian Amazon. GCB Bioenergy 5:384-90.

Fujisaka S, White D. 1998. Pasture or permanent crops after slash-and-burn cultivation? Land-use choice in three Amazon colonies. Agrofor Syst 42:45-59.

Galván O, Sabogal Meléndez C, Colán Colán V. 2000. Inventario forestal en bosques secundarios de colonos en tres sectores de la zona de Pucallpa, Amazonía Peruana.

Gamarra LV, Martínez RV, Gonzáles RR, Valdivia MIV, Phillips O, González GL, Moscoso VC, Mendoza AM, Camacho CP. 2015. Línea base para el monitoreo de la vegetación en la Reserva Comunal El Sira (RCS):26.

Gentry AH. 1996. A field guide to the families and genera of woody plants of northwest South America (Colombia, Ecuador, Peru), with supplementary notes on herbaceous taxa. University of Chicago. Chicago: University of Chicago Press. 
Germer J, Sauerborn J. 2008. Estimation of the impact of oil palm plantation establishment on greenhouse gas balance. Environ Dev Sustain 10:697-716.

Glinskis EA, Gutiérrez-Vélez VH. 2019. Quantifying and understanding land cover changes by large and small oil palm expansion regimes in the Peruvian Amazon. Land Use Policy 80:95-106.

Gobierno Regional de Ucayali. 2015. Estudio fisiografía del departamento de Ucayali. http://geoservidor.minam.gob.pe/z ee-aprobadas/ucayali/. Last accessed 30/07/2018.

Gobierno Regional de Ucayali. 2016a. Ordenanza regional $\mathrm{N}^{\mathrm{o}}$ 006-2016-GRU-CR. Plan de Competitividad de la Palma Aceitera Ucayali 2016-2026.

Gobierno Regional de Ucayali. 2016b. Zonificación ecológica y económica de la región Ucayali: Estudio de clima y zonas de vida. http://geoservidor.minam.gob.pe/zee-aprobadas/ucayal i/. Last accessed 29/07/2018.

Gobierno Regional de Ucayali. 2016c. Zonificación ecológica y económica de la región Ucayali: Estudio de suelos y capacidad de uso mayor de las tierras. http://geoservidor.minam.gob.pe/ zee-aprobadas/ucayali/. Last accessed 26/07/2018.

Goodman RC, Phillips OL, Baker TR. 2014. The importance of crown dimensions to improve tropical tree biomass estimates. Ecol Appl 24:680-98.

Guillaume T, Kotowska MM, Hertel D, Knohl A, Krashevska V, Murtilaksono K, Scheu S, Kuzyakov Y. 2018. Carbon costs and benefits of Indonesian rainforest conversion to plantations. Nature Communications 9. http://www.nature.com/a rticles/s41467-018-04755-y. Last accessed 06/09/2019.

Gutiérrez-Vélez VH, DeFries R, Pinedo-Vásquez M, Uriarte $M$, Padoch C, Baethgen W, Fernandes K, Lim Y. 2011. High-yield oil palm expansion spares land at the expense of forests in the Peruvian Amazon. Environ Res Lett 6:044029.

Hall JS, Harris DJ, Medjibe V, Ashton PMS. 2003. The effects of selective logging on forest structure and tree species composition in a Central African forest: implications for management of conservation areas. For Ecol Manage 183:249-64.

Henson IE. 2009a. Comparative ecophysiology of oil palm and tropical rain forest. In: Singh G, Lim KH, Chan KW, editors. Sustainable Production of Palm Oil: a Malaysian Experience. Kuala Lumpur: Malaysian Palm Oil Association. pp 1-51.

Henson IE. 2009b. Modelling carbon sequestration and greenhouse gas emissions associated with oil palm cultivation and land-use change in Malaysia. A re-evaluation and a computer model. Kuala Lumpur: Malaysian Palm Oil Board.

Henson IE. 2017. A review of models for assessing carbon stocks and carbon sequestration in oil palm plantations. J Oil Palm Res 29:1-10.

Hergoualc'h K, Blanchart E, Skiba U, Hénault C, Harmand J-M. 2012. Changes in carbon stock and greenhouse gas balance in a coffee (Coffea arabica) monoculture versus an agroforestry system with Inga densiflora, in Costa Rica. Agr Ecosyst Environ 148:102-10.

Honorio-Coronado EN, Vega-Arenas JE, Corrales-Medina MN. 2015. Diversidad, estructura y carbono de los bosques aluviales del Noreste Peruano. Folia Amazónica 24:55.

Jakovac CC, Bongers F, Kuyper TW, Mesquita RCG, Peña-Claros M. 2016. Land use as a filter for species composition in Amazonian secondary forests. Nakashizuka T, editor. J Veg Sci 27:1104-16.
Kauffman JB, Donato DC. 2012. Protocols for the Measurement, Monitoring and Reporting of Structure, Biomass, and Carbon Stocks in Mangrove Forests. CIFOR Working paper 86:61.

Khalid H, Zin ZZ, Anderson JM. 1999. Quantification of oil palm biomass and nutrient value in a mature plantation. II. Belowground biomass. J Oil Palm Res 11:63-71.

Khasanah N, van Noordwijk M, Ningsih H. 2015a. Aboveground carbon stocks in oil palm plantations and the threshold for carbon-neutral vegetation conversion on mineral soils. Wich S, editor. Cogent Environmental Science 1. https://www.coge ntoa.com/article/10.1080/23311843.2015.1119964. Last accessed 17/07/2018.

Khasanah N, van Noordwijk M, Ningsih H, Rahayu S. 2015b. Carbon neutral? No change in mineral soil carbon stock under oil palm plantations derived from forest or non-forest in Indonesia. Agr Ecosyst Environ 211:195-206.

Kindt R, Coe R. 2005. Tree diversity analysis: a manual and software for common statistical methods for ecological and biodiversity studies. Nairobi, Kenya: World Agrofirestry Centre.

Kommeter R. 1987. Inventario forestal de los bosques secundarios de Pucallpa. Universidad Nacional Agraria la Molina.

Lapeyre T, Alegre J, Arévalo L. 2004. Determinación de las reservas de carbono de la biomasa aérea, en diferentes sistemas de uso de la tierra en San Martín, Perú. Ecol Appl 3:35.

Lo E. 2005. Gaussian error propagation applied to ecological data: post-ice-storm-downed woody biomass. Ecol Monogr 75:451-66.

Meza Doza E. 2016. Estimación del carbono almacenado en la biomasa forestal y suelo de una concesión maderable ubicada en el distrito de Masisea, provincia de Coronel Portillo, Departamento de Ucayali, Perú.

Ministerio de Agricultura. 1999. Perú Forestal en números año 1998. https://www.serfor.gob.pe/wp-content/uploads/2016/0 3/Peru_Forestal_1998.pdf. Last accessed 09/05/2018.

Ministerio de Agricultura. 2001. Plan Nacional de la promoción de Palma Aceitera, Perú 2000-2010.

Ministerio de Agricultura. 2016. Plan Nacional de Desarrollo Sostenible de la Palma Aceitera del Perú. https://docplayer.es/ 33207799-Plan-nacional-de-desarrollo-sostenible-de-la-palm a-aceitera-en-el-peru.html. Last accessed 30/08/2018.

Ministerio del Ambiente. 2015. Mapa nacional de cobertura vegetal: memoria descriptiva. http://www.minam.gob.pe/pat rimonio-natural/wp-content/uploads/sites/6/2013/10/MAP A-NACIONAL-DE-COBERTURA-VEGETAL-FINAL.compresse d.pdf. Last accessed 08/12/2018.

Ministerio del Ambiente. 2016. Estrategia Nacional sobre bosques y cambio climático. http://www.bosques.gob.pe/archiv o/ff3f54_ESTRATEGIACAMBIOCLIMATICO2016_ok.pdf. Last accessed 08/08/2018.

Mokany K, Raison RJ, Prokushkin AS. 2006. Critical analysis of root: shoot ratios in terrestrial biomes. Glob Change Biol 12:84-96.

Nebel G, Kvist LP, Vanclay JK, Christensen H, Freitas L, Ruíz J. 2001. Structure and floristic composition of flood plain forests in the Peruvian Amazon. For Ecol Manage 150:27-57.

Oficina Nacional de Evaluacion de Recursos Naturales. 1983. Inventario y evaluación semidetallada de los recursos naturales de la zona del río Pachitea. Lima.

Oktarita S, Hergoualc'h K, Anwar S, Verchot LV. 2017. Substantial $\mathrm{N}_{2} \mathrm{O}$ emissions from peat decomposition and $\mathrm{N}$ fertil- 
ization in an oil palm plantation exacerbated by hotspots. Environ Res Lett 12:104007.

Orihuela-Belmonte DE, de Jong BHJ, Mendoza-Vega J, Van der Wal J, Paz-Pellat F, Soto-Pinto L, Flamenco-Sandoval A. 2013. Carbon stocks and accumulation rates in tropical secondary forests at the scale of community, landscape and forest type. Agr Ecosyst Environ 171:72-84.

Palace M, Keller M, Hurtt G, Frolking S. 2012. A Review of Above Ground Necromass in Tropical Forests. In: Sudarshana P, editor. Tropical Forests. InTech. pp 215-52. http://www. intechopen.com/books/tropical-forests/a-review-of-above-gro und-necromass-in-tropical-forests. Last accessed 06/12/2018.

Pallqui NC, Monteagudo A, Phillips OL, Lopez-Gonzalez G, Cruz L, Galiano W, Chavez W, Vasquez R. 2014. Dinámica, biomasa aérea y composición florística en parcelas permanentes Reserva Nacional Tambopata, Madre de Dios, Perú. Revista Peruana de Biología 21. http://revistasinvestigacion.unmsm. edu.pe/index.php/rpb/article/view/10897. Last accessed 16/ 07/2018.

Pennington TD, Reynel C, Daza A, Wise R. 2004. Illustrated guide to the trees of Peru. Sherborne:DH.

Peru. 2015. Intended nationally determined contribution (iNDC). http://www4.unfccc.int/submissions/INDC/Submis sion \% 20Pages/Submissions.aspx. Last accessed 15/09/2018.

Phillips OL, Vásquez Martínez R, Núñez Vargas P, Lorenzo Monteagudo A, Chuspe Zans M-E, Galiano Sánchez W, Peña Cruz A, Timaná M, Yli-Halla M, Rose S. 2003. Efficient plotbased floristic assessment of tropical forests. J Trop Ecol 19:629-45.

Phillips OL, Baker T, Feldpausch T, Brienen R. 2016. RAINFOR field manual for plot establishment and remeasurement. $\mathrm{h}$ ttp://www.rainfor.org/upload/ManualsEnglish/RAINFOR_fiel d_manual_version_2016.pdf. Last accessed 15/11/2018.

Pinzon A. 2018. Sustainable Palm Oil Production in Peru. Global Canopy https://www.globalcanopy.org/sites/default/files/doc uments/resources/SustainablePalmOilProductioninPeru.pdf. Last accessed 04/05/2019.

Poorter L, Bongers F, Aide TM, Almeyda Zambrano AM, Balvanera P, Becknell JM, Boukili V, Brancalion PHS, Broadbent EN, Chazdon RL, Craven D, de Almeida-Cortez JS, Cabral GAL, de Jong BHJ, Denslow JS, Dent DH, DeWalt SJ, Dupuy JM, Durán SM, Espírito-Santo MM, Fandino MC, César RG, Hall JS, Hernandez-Stefanoni JL, Jakovac CC, Junqueira AB, Kennard D, Letcher SG, Licona J-C, Lohbeck M, Marín-Spiotta E, Martínez-Ramos M, Massoca P, Meave JA, Mesquita R, Mora F, Muñoz R, Muscarella R, Nunes YRF, Ochoa-Gaona S, de Oliveira AA, Orihuela-Belmonte E, Peña-Claros M, PérezGarcía EA, Piotto D, Powers JS, Rodríguez-Velázquez J, Romero-Pérez IE, Ruíz J, Saldarriaga JG, Sanchez-Azofeifa A, Schwartz NB, Steininger MK, Swenson NG, Toledo M, Uriarte $M$, van Breugel $M$, van der Wal H, Veloso MDM, Vester HFM, Vicentini A, Vieira ICG, Bentos TV, Williamson GB, Rozendaal DMA. 2016. Biomass resilience of Neotropical secondary forests. Nature 530:211-14.

Potapov PV, Dempewolf J, Talero Y, Hansen MC, Stehman SV, Vargas C, Rojas EJ, Castillo D, Mendoza E, Calderón A, Giudice R, Malaga N, Zutta BR. 2014. National satellite-based humid tropical forest change assessment in Peru in support of REDD+ implementation. Environ Res Lett 9:124012.

Potter L. 2015. Managing oil palm landscapes: a seven-country survey of the modern palm oil industry in Southeast Asia, Latin America and West Africa. Center for International Forestry Research (CIFOR).
Quezada JC, Etter A, Ghazoul J, Buttler A, Guillaume T. 2019. Carbon neutral expansion of oil palm plantations in the Neotropics. Science advances 5:eaaw4418.

Ríos Trigoso J. 1990. Manual de los arboles más comunes de los bosques secundarios de Pucallpa. Lima: PUBS, Facultad de Ciencias Forestales de la Universidad Nacional Agraria La Mollina.

Rozendaal DMA, Bongers F, Aide TM, Alvarez-Dávila E, Ascarrunz N, Balvanera P, Becknell JM, Bentos TV, Brancalion PHS, Cabral GAL, Calvo-Rodriguez S, Chave J, César RG, Chazdon RL, Condit R, Dallinga JS, de Almeida-Cortez JS, de Jong B, de Oliveira A, Denslow JS, Dent DH, DeWalt SJ, Dupuy JM, Durán SM, Dutrieux LP, Espírito-Santo MM, Fandino MC, Fernandes GW, Finegan B, García H, Gonzalez N, Moser VG, Hall JS, Hernández-Stefanoni JL, Hubbell S, Jakovac CC, Hernández AJ, Junqueira AB, Kennard D, Larpin D, Letcher SG, Licona J-C, Lebrija-Trejos E, Marín-Spiotta E, Martínez-Ramos M, Massoca PES, Meave JA, Mesquita RCG, Mora F, Müller SC, Muñoz R, de Oliveira Neto SN, Norden N, Nunes YRF, Ochoa-Gaona S, Ortiz-Malavassi E, Ostertag R, Peña-Claros M, Pérez-García EA, Piotto D, Powers JS, AguilarCano J, Rodriguez-Buritica S, Rodríguez-Velázquez J, Romero-Romero MA, Ruíz J, Sanchez-Azofeifa A, de Almeida AS, Silver WL, Schwartz NB, Thomas WW, Toledo M, Uriarte M, de Sá Sampaio EV, van Breugel M, van der Wal H, Martins SV, Veloso MDM, Vester HFM, Vicentini A, Vieira ICG, Villa P, Williamson GB, Zanini KJ, Zimmerman J, Poorter L. 2019. Biodiversity recovery of Neotropical secondary forests. Sci Adv 5:eaau3114.

Smith J. 1999. Dynamics of secondary forests in slash-and-burn farming: interactions among land use types in the Peruvian Amazon. Agr Ecosyst Environ 76:85-98.

Smith SD, Bunting SC, Hironaka M. 1986. Sensitivity of frequency plots for detecting vegetation change. North Sci 60:279-86.

Sy VD, Herold M, Achard F, Beuchle R, Clevers JGPW, Lindquist E, Verchot L. 2015. Land use patterns and related carbon losses following deforestation in South America. Environ Res Lett 10:124004.

Syahrinudin S. 2005. The potential of oil palm and forest plantations for carbon sequestration on degraded land in Indonesia. In: Viek PLG, Denich M, Martius C, Rodgers C, van de Giesen N, Cuvillier Verlag N, editors. Ecology and development series. No 28. Göttingen.

Tournon J, Riva R. 2001. Bosques primarios y secundarios de una comunidad nativa del Ucayali. Revista Forestal del Perú XXIV:7-18.

van Straaten O, Corre MD, Wolf K, Tchienkoua M, Cuellar E, Matthews RB, Veldkamp E. 2015. Conversion of lowland tropical forests to tree cash crop plantations loses up to onehalf of stored soil organic carbon. Proc Natl Acad Sci 112:9956-60.

Vargas Gonzáles C, Rojas Baez E, Castillo Soto D, Espinoza Mendoza V, Calderón-Urquizo Carbajal A, Giudice Granados R, Málaga Durán N. 2014. Protocolo de Clasificación de Pérdida de Cobertura en los Bosques Húmedos Amazónicos entre los años 2000-2011.

Vijay V, Reid CD, Finer M, Jenkins CN, Pimm SL. 2018. Deforestation risks posed by oil palm expansion in the Peruvian Amazon. Environ Res Lett 13:114010.

Wittmann F, Schongart J, Montero JC, Motzer T, Junk WJ, Piedade MTF, Queiroz HL, Worbes M. 2006. Tree species 
composition and diversity gradients in white-water forests across the Amazon Basin. J Biogeogr 33:1334-47.

Zanne AE, Lopez-Gonzalez G, Coomes DA, Ilic J, Jansen S, Lewis SL, Miller RB, Swenson NG, Wiemann MC, Chave J. 2009.
Data from: Towards a worldwide wood economics spectrum. h ttps://datadryad.org/resource/doi.org/10.5061/dryad.234. Last accessed 06/09/2019. 